\title{
ANALISIS PENERAPAN \\ LOCATION BASED SERVICE (LBS) PADA SMARTPHONE
}

\section{PENULISAN ILMIAH}

oleh

Yuliani Wijaya

14411036

PROGRAM STUDI SISTEM INFORMASI

FAKULTAS ILMU KOMPUTER

UNIVERSITAS BANDAR LAMPUNG

2017 


\section{ANALISIS PENERAPAN \\ LOCATION BASED SERVICE (LBS) PADA SMARTPHONE}

\section{PENULISAN ILMIAH}

(Diajukan sebagai salah satu syarat untuk mengambil Tugas Akhir Strata-1 (S1) pada Program Studi Sistem Informasi Fakultas Ilmu Komputer Universitas Bandar Lampung)

oleh:

Yuliani Wijaya

14411036

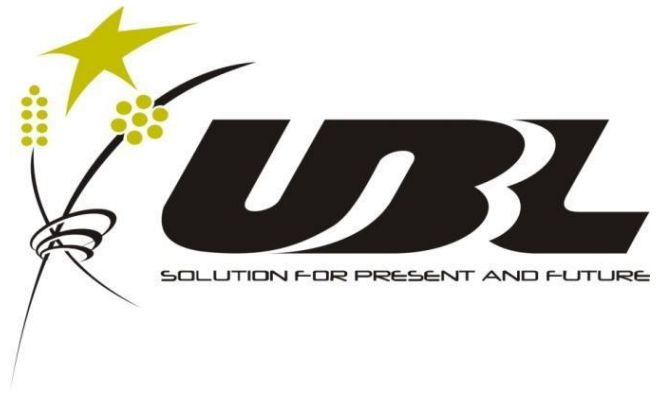

PROGRAM STUDI SISTEM INFORMASI

FAKULTAS ILMU KOMPUTER

UNIVERSITAS BANDAR LAMPUNG

2017 


\title{
HALAMAN PENGESAHAN
}

\author{
Judul Penulisan Ilmiah \\ : ANALISIS PENERAPAN LOCATION BASED \\ SERVICE (LBS) PADA SMARTPHONE \\ Nama Mahasiswa \\ : Yuliani Wijaya \\ No.Pokok Mahasiswa \\ : 14411036 \\ Program Studi \\ : Sistem Informasi \\ Fakultas \\ : Ilmu Komputer
}

Bandar Lampung, 23 Februari 2017

\section{MENGESAHKAN}

Dosen Pembimbing

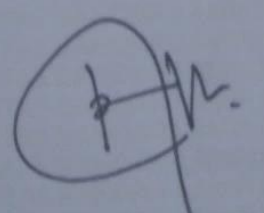

Erlangga, S.Kom., M.Kom.
Ketua Program Studi

Sistem Informasi

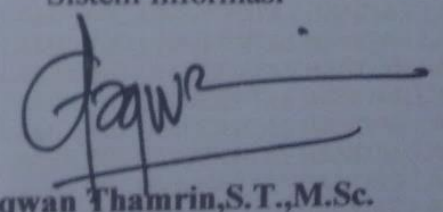




\section{MENGESAHKAN}

Tim Penguji

Ketua

Sekretaris

Penguji Utama

: Ayu Kartika Puspa.,,M.Ti

: Wiwin Susanty,S.Kom.,M.Kom

: Yuthsi Aprilinda, S.Kom., M.Kom

MENGETAHUI

Dekgn Fakatitas flmu Komputer

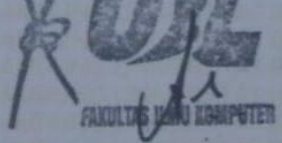

Ahmad Cucus, S.Kom., M.Kom.
Tanda Tangan
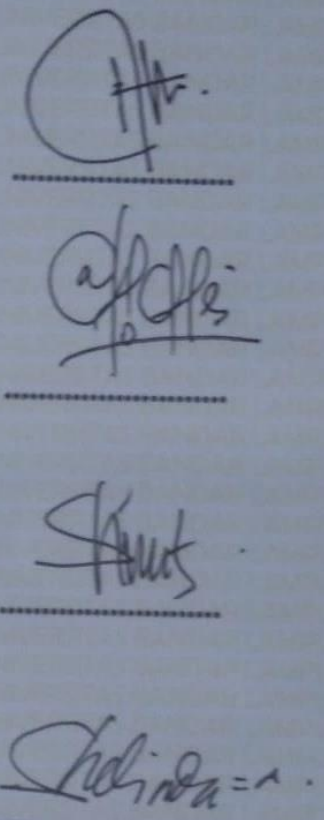


\begin{abstract}
ABSTRAK
Kemajuan teknologi diikuti banyak perkembangan aplikasi, salah satunya aplikasi pemetaan, aplikasi pemetaan digunakan untuk menampilkan peta dan informasi dari objek yang dipilih. Aplikasi berbasis lokasi ini bertujuan untuk mencari tahu lokasi-lokasi yang belum diketahui sebelumnya hanya melalui smartphone. Metode yang dibahas dalam penelitian ini adalah Location Based Service (LBS). Penelitian ini membandingkan beberapa jurnal yang mengimplementasikan LBS pada aplikasi yang dibuat. Hasil dari penelitian ini adalah bahwa dengan perancangan aplikasi menggunakan metode Location Based Service (LBS) terbukti dapat membantu dalam menampilkan posisi saat ini secara geografis yang didapat dari perangkat bergerak atau smartphone dan dapat berfungsi sebagai alat penunjuk lokasi sehingga dapat mempermudah dalam mencari sebuah lokasi atau objek yang dituju.
\end{abstract}

Kata Kunci: Komparasi, Location Based Service, LBS, Lokasi, Smartphone 


\section{KATA PENGANTAR}

Puji syukur kehadirat Allah SWT atas rahmat dan karunia Nya penulis dapat diberi kesehatan dan dapat menyelesaikan penulisan ilmiah yang berjudul "Analisis Penerapan Location Based Service (LBS) pada Smartphone”. Penulisan ilmiah ini diajukan sebagai salah satu syarat untuk dapat mengambil Tugas Akhir (TA).

Penulis menyadari bahwa didalam penulisan ilmiah ini tidak dapat terselesaikan dengan baik tanpa adanya bantuan dan bimbingan dari berbagai pihak. Oleh karena itu pada kesempatan ini penulis ingin mengucapkan terima kasih kepada:

1. Ibu Dra. Hj. Sri Hayati Barusman, selaku Ketua Pembina Yayasan Administrasi Universitas Bandar Lampung.

2. Bapak Dr. Ir. H. Yusuf Sulfarano Barusman, MBA, selaku Rektor Universitas Bandar Lampung.

3. Bapak Dr. Andala Rama Putra Barusman, SE., MA.Ec., selaku Direktur Eksekutif Yayasan Universitas Bandar Lampung.

4. Bapak Ahmad Cucus, S.Kom., M.Kom. selaku dekan Fakultas Ilmu Komputer Universitas Bandar Lampung.

5. Bapak Erlangga, S.Kom., M.Kom. selaku dosen Pembimbing Akademik sekaligus Pembimbing Penulisan Ilmiah ini.

6. Dosen yang telah membantu memberi arahan dan bimbingan dalam menyelesaikan penulisan ilmiah ini.

7. Orang tua dan keluarga yang telah memberikan doa dan dukungan baik materil dan dukungan moril dalam menyelesaikan penulisan ilmiah ini.

8. Teman-teman dekat Fitria, Tiya, Sri Ayu dan teman-teman yang tidak dapat disebutkan satu persatu yang sudah membantu dan mendukung penulis dalam menyelesaikan penulisan ilmiah. 
Penulis menyadari bahwa penulisan ilmiah ini masih banyak kekurangan, oleh karena itu diharapkan kritik dan saran yang membangun untuk penulis agar dapat mengembangkan penulisan ini, semoga penulisan ini bermanfaat bagi penulis khususnya dan pembaca pada umumnya.

Bandar Lampung, Februari 2017

Penulis 


\section{DAFTAR ISI}

HALAMAN PENGESAHAN ................................................................. $\mathrm{i}$

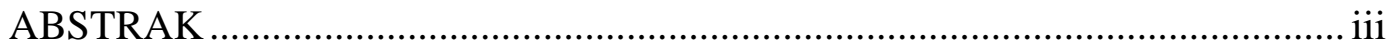

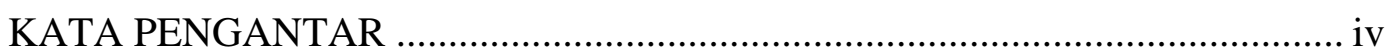

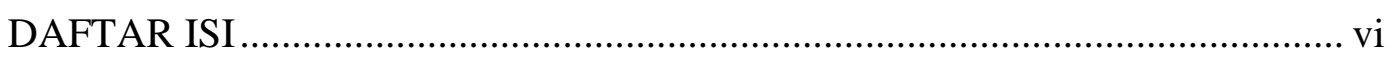

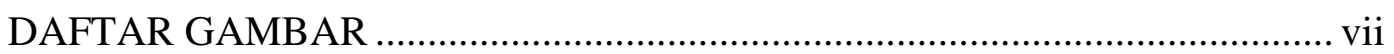

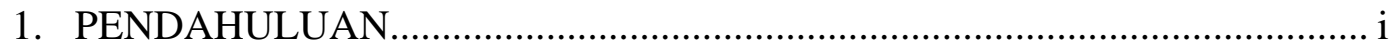

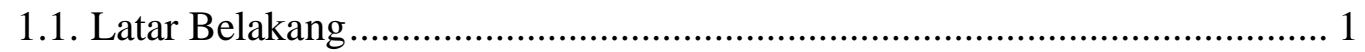

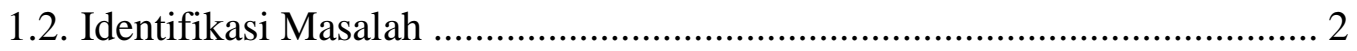

1.3. Ruang Lingkup Masalah.......................................................................... 2

1.4. Rumusan Masalah........................................................................................ 2

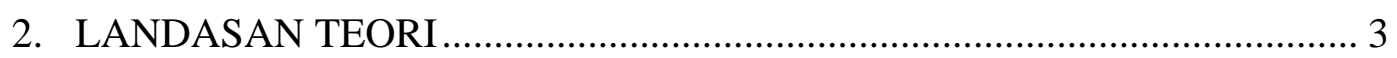

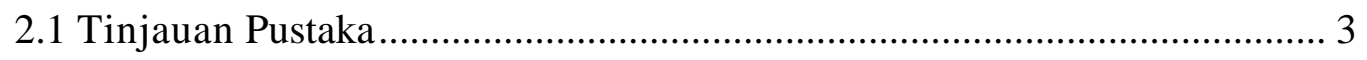

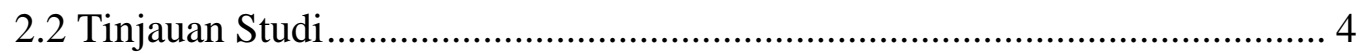

3. TUJUAN DAN MANFAAT PENELITIAN ............................................. 8

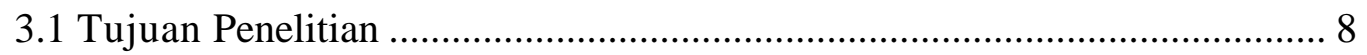

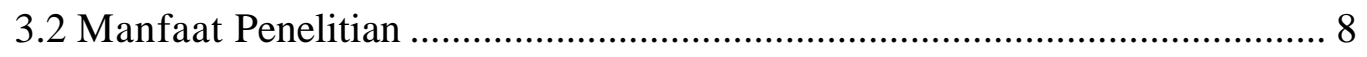

4. METODOLOGI PENELITIAN ............................................................. 9

4.1 Jenis Penelitian ..................................................................................... 9

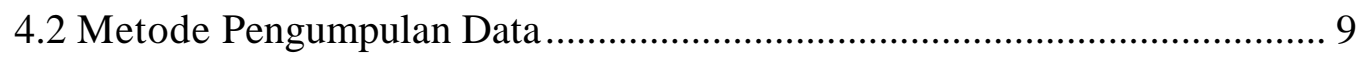

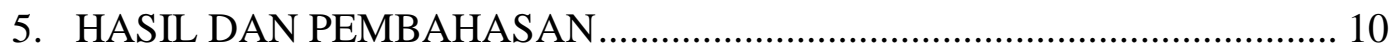

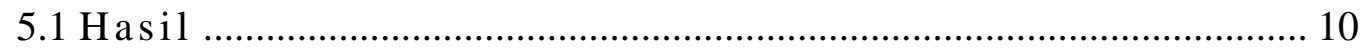

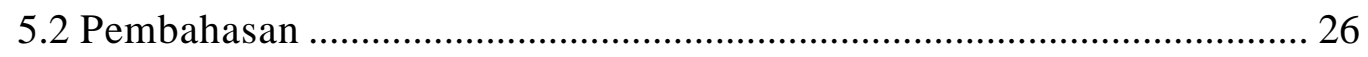

6. RENCANA PENELITIAN BERIKUTNYA .............................................. 29

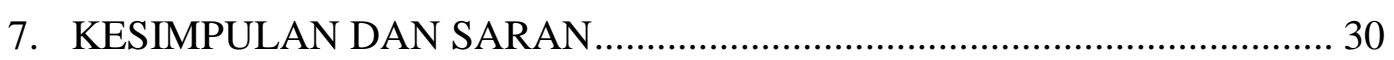

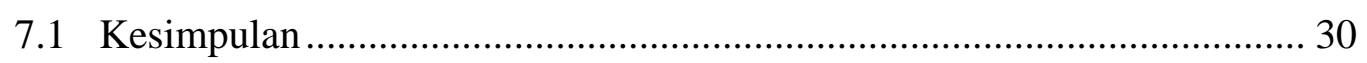

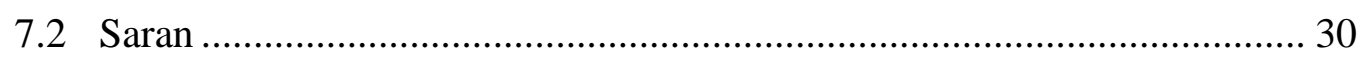

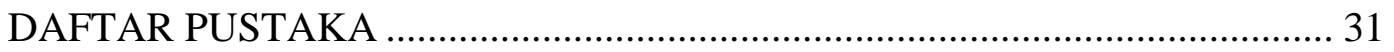

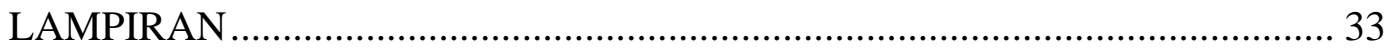

Lampiran 1. Form Kegiatan Bimbingan Penulisan Ilmiah ............................... 33

Lampiran 2. Form Perbaikan Sidang Penulisan Ilmiah .................................. 35

Lampiran 3. Berita Acara Cetak Softcover..................................................... 36 


\section{DAFTAR GAMBAR}

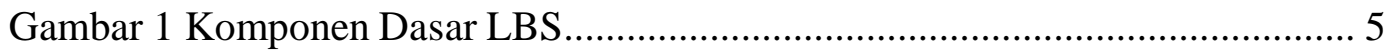

Gambar 2 Arsitektur Aplikasi LBS Rumah Sakit .............................................. 10

Gambar 3 Usecase Aplikasi LBS Rumah Sakit Yogyakarta Pada Android ......... 11

Gambar 4 Rancangan Antar Muka Sub Menu .................................................... 12

Gambar 5 Rancangan Antarmuka Submenu Antarmuka Peta dan Jarak .............. 13

Gambar 6 Rancangan Antarmuka Peta ........................................................... 13

Gambar 7 Alur Perancangan Sistem .............................................................. 14

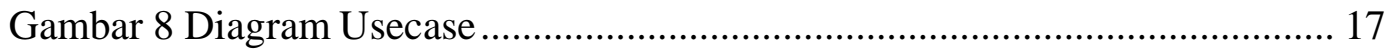

Gambar 9 Diagram Usecase Administrator .................................................. 17

Gambar 10 Diagram Aktivitas Melihat Koordinat Posisi ................................... 18

Gambar 11 Diagram Aktivitas Melihat Daftar Perguruan Tinggi ....................... 18

Gambar 12 Diagram Aktivitas Melihat Lokasi-Lokasi Perguruan Tinggi ............ 19

Gambar 13 Tampilan Posisiku .................................................................... 19

Gambar 14 Tampilan Menu Utama................................................................ 21

Gambar 15 Tampilan Halaman Infrormasi...................................................... 22

Gambar 16 Halaman Pencarian Rute Pariwisata.................................................. 22

Gambar 17 Halaman Google Maps ....................................................................... 23

Gambar 18 Halaman Rute Pariwisata _.............................................................. 23

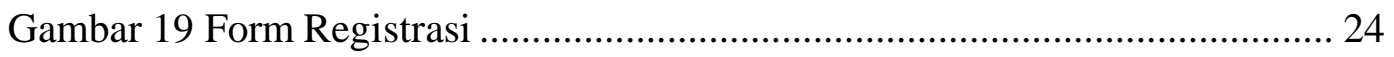

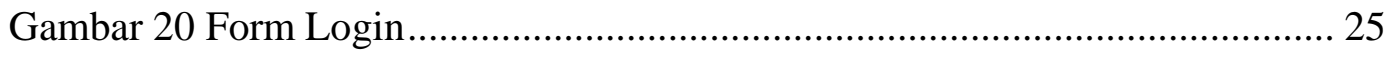

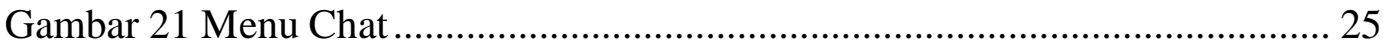

Gambar 22 Kerangka Berpikir Rencana Penelitian Berikutnya ......................... 29 


\section{PENDAhULUAN}

Pada pendahuluan akan dikemukakan tentang latar belakang, identifikasi masalah, ruang lingkup masalah, dan rumusan masalah.

\subsection{Latar Belakang}

Saat ini dengan semakin pesatnya perkembangan teknologi dan internet, telah memiliki dampak yang besar terhadap perubahan teknologi. Penelitian ini berfokus pada pemanfaatan teknologi yang dibutuhkan untuk mendapatkan informasi dengan cepat, dimana pemanfaatan teknologi dapat diakses dimanapun dan kapanpun penggunanya berada. Dengan menggunakan perangkat mobile, informasi akan lebih mudah didapat dimanapun dan kapanpun, perangkat mobile yang saat ini paling banyak digunakan adalah smartphone dengan sistem operasi Android (Erlangga \& Furqon, 2014), (Putra, 2014).

Android adalah sistem operasi untuk telepon seluler yang berbasis Linux. Android menyediakan platform yang bersifat open source bagi para pengembang untuk menciptakan sebuah aplikasi. Awalnya, Google Inc. mengakuisi Android Inc. Yang mengembangkan software untuk ponsel yang berada di Palo Alto, California Amerika Serikat (Nasruddin, sebagai mana dikutip dari Santoso, 2016).

Kemajuan teknologi ini diikuti banyak perkembangan aplikasi, salah satunya aplikasi pemetaan, aplikasi ini digunakan untuk menampilkan peta dan informasi dari objek yang dipilih. Aplikasi berbasis lokasi ini bertujuan untuk mencari tahu lokasi-lokasi yang belum diketahui sebelumnya hanya melalui smartphone. Metode yang dibahas dalam perancangan aplikasi mobile berbasis lokasi pada penulisan ini adalah Location Based Service (LBS).

LBS atau layanan berbasis lokasi adalah sebuah layanan informasi yang dapat diakses dengan perangkat bergerak melaui jaringan dan mampu menampilkan posisi secara geografis, sesuai dengan keberadaan perangkat bergerak tersebut. LBS juga dapat berfungsi sebagai layanan untuk mengidentifikasi lokasi dari seseorang atau suatu objek tertentu. 
Penelitian ini membahas mengenai metode LBS untuk menemukan suatu objek atau lokasi dengan menggunakan Android. Berdasarkan uraian diatas maka penulis memberi judul "Analisis Implementasi Location Based Service (LBS) pada Smartphone".

\subsection{Identifikasi Masalah}

Adapun identifikasi masalah dalam penulisan ilmiah ini yaitu kurangnya informasi tentang lokasi suatu objek sehingga membuat warga/ masyarakat yang tidak mengetahui informasi lokasi suatu objek tersebut merasa kesulitan dalam mencari tempat atau lokasi yang dituju.

\subsection{Ruang Lingkup Masalah}

Adapun ruang lingkup dalam penulisan ilmiah ini yaitu pada ruang lingkup jurnal dalam pencarian lokasi, meliputi rumah sakit, perguruan tinggi, tempat pariwisata dan pencarian lokasi seseorang yang sedang memerlukan bantuan; pembahasan sistem hanya pada perangkat mobile dengan operasi Android dan metode yang digunakan adalah LBS.

\subsection{Rumusan Masalah}

Rumusan masalah dalam penulisan ilmiah ini adalah "Bagaimana implementasi Location Based Service (LBS) untuk menunjukan suatu tempat/ lokasi pada aplikasi mobile?”. 


\section{LANDASAN TEORI}

Pada landasan teori akan dikemukakan tentang tinjauan pustaka dan tinjauan studi. Tinjauan pustaka merupakan uraian sistematis tentang hasil-hasil penelitian yang telah dilakukan oleh peneliti terdahulu dan memiliki hubungan dengan penelitian yang akan dilakukan. Tinjauan pustaka yang akan dipaparkan adalah variabel dan sub variabel yang digunakan dalam penelitian.

\subsection{Tinjauan Pustaka}

Tinjauan pustaka yang digunakan pada penelitian ini diambil dari 4 penelitian terdahulu yang memiliki keterkaitan dengan penelitian ini.

a. Jurnal Seminar Nasional Informatika 2013 (semnasIF 2013) ISSN: 19792328 UPN "Veteran" Yogyakarta, 18 Mei 2013 dengan judul artikel jurnal Perancangan Aplikasi Location Based Service Rumah Sakit Yogyakarta pada Android oleh Ragil Tri Dianti Putri, dkk; dijelaskan bahwa aplikasi Location Based Service Rumah Sakit Yogyakarta pada Android ini dapat membatu pengguna dalam memberikan informasi tentang rumah sakit yang ada di Yogyakarta, sehingga pengguna tidak mengalami kesulitan dalam mencari lokasi rumah sakit di Yogyakarta.

b. Jurnal Teknologi dan Sistem Komputer (JTsiskom 2015) Vol.3, No.2, April 2015 e-ISSN: 2338-0403, dengan judul artikel jurnal Aplikasi Pencarian Rute Perguruan Tinggi Berbasis Android Menggunakan Location Based Service (LBS) di Kota Semarang oleh Satriaji Cahyo Nugroho dkk; dijelaskan bahwa aplikasi pencarian rute perguruan tinggi berbasis LBS dapat memudahkan pengguna dalam mendapatkan informasi dan menentukan rute karena data informasi dan letak lokasi-lokasi perguruan tinggi telah didaftarkan oleh peneliti, hasil analisis dan pengujian cepat lambatnya koneksi internet sangat mempengaruhi proses jalannya aplikasi karena aplikasi menggunakan teknologi Google Maps dan pengambilan data dari database server. 
c. Jurnal International Journal of Advanced Computer Science and Applications (IJACSA), Vol. 6, No. 8, 2015 dengan judul jurnal Implementation of Location Base Service on Tourism Places in West Nusa Tenggara by Using Smartphone oleh Karya Gunawan dan Bambang Eka Purnama menerangkan bahwa berdasarkan korespondensi antara input, proses, dan output, dapat disimpulkan bahwa aplikasi Pariwisata dapat berjalan dengan baik pada Android atau Smartphone. Aplikasi ini dapat dijalankan jika Smartphone memiliki akses yang baik ke Internet dan memiliki GPS aktif. Aplikasi wisata memberikan kemudahan bagi para wisatawan ketika mengunjungi Nusa Tenggara Barat dalam menemukan situs Pariwisata.

d. Jurnal International Journal of Science, Engineering and Technology Research (IJSETR), ISSN: 2278 - 7798, Volume 3, Issue 3, March 2014, dengan judul jurnal Providing Emergency Services Using Location Based Tracking on Mobile Devices oleh Ankita Deshpande, dkk; menerangkan bahwa Location Based Service dapat meningkatkan layanan darurat layanan berbasis lokasi ini berguna untuk meningkatkan kinerja layanan darurat. Aplikasi ini berfokus kepada penyediaan tanggapan langsung dalam keadaan darurat dan memberikan bantuan untuk orang-orang yang terjebak di suatu daerah yang dengan melacak lokasi mereka dan dengan demikian aplikasi ini akan terbukti efisien untuk meningkatkan efektivitas pelayanan kesehatan.

\subsection{Tinjauan Studi}

Tinjauan studi dalam penelitian ini adalah sebagai berikut:

a. Location Based Service (LBS)

Location Based Service yang selanjutnya disingkat LBS adalah layanan informasi yang dapat diakses menggunakan peranti mobile melalui jaringan internet dan seluler serta memanfaatkan kemampuan penunjuk lokasi pada peranti mobile. LBS melakukan komunikasi dan interaksi dua arah. LBS dapat digambarkan sebagai suatu layanan yang berada pada pertemuan tiga teknologi yaitu: Geographic Information System, Internet Service, dan Mobile Devices. (Andri Ferinata, dkk, 2012 sebagaimana dikutip dari Razaq dan Janato, 2014). Secara garis besar jenis layanan berbasis lokasi ini juga dapat dibagi menjadi dua, yaitu Pull 
Servuce dan Push Service. Pull Service yaitu layanan diberikan berdasarkan permintaan dari pelanggan akan kebutuhan suatu informasi. Sementara Push Service yaitu layanan yang diberikan langsung oleh service provider tanpa menunggu permintaan dari pelanggan. Layanan Berbasis Lokasi terdiri 5 komponen utama yaitu: (Akbar, 2011), (Amit Kuswaha, 2011).

1) Mobile Devices: Suatu alat yang digunakan oleh pengguna untuk meminta informasi yang dibutuhkan.

2) Communication Network: Jaringan komunikasi yang mengirim data pengguna dan informasi yang diminta dari mobile terminal ke service provider kemudian mengirimkan kembali informasi yang diminta ke pengguna. Communication network dapat berupa jaringan seluler (GSM, CDMA), Wireless Local Area Network (WLAN), atau Wireless Wide Area Network (WWAN).

3) Positioning Component: Untuk memproses sesuatu dalam mengendalikan layanan maka posisi pengguna harus diketahui peta.

4) Service and Application Provider: Penyedia layanan menawarkan berbagai macam layanan kepada pengguna dan bertanggung jawab untuk memproses informasi yang diminta oleh pengguna.

5) Data and Content Provider: Penyedia layanan tidak selalu menyimpan semua data yang dibutuhkan yang bisa diakses oleh pengguna Untuk itu, data dapat diminta dari content provider.

Komponen dasar LBS digambarkan pada Gambar 1:

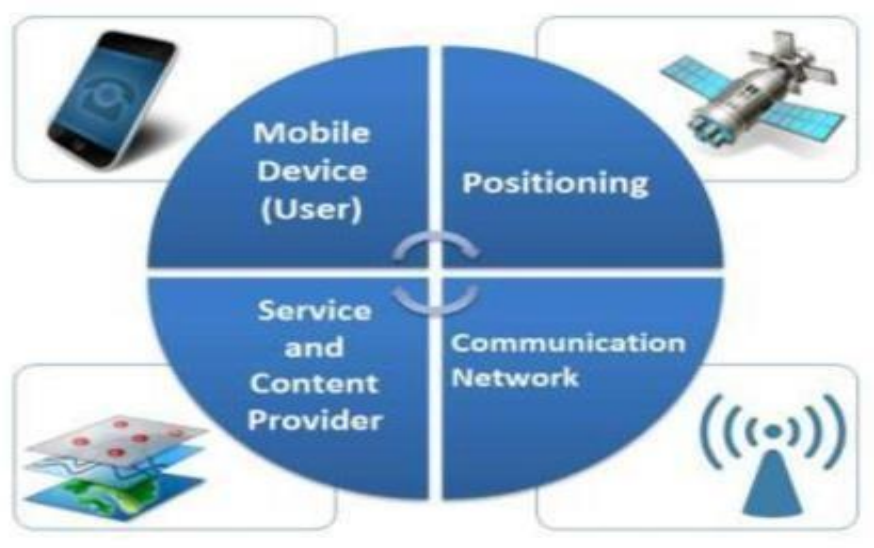

Gambar 1 Komponen Dasar LBS 
b. Android

Menurut Wicak Hidayat \& Sudarma S dalam bukunya yang berjudul Buku Pintar Komputer Laptop Netbook \& Tablet iPad \& Android Plus Internet (2011, p192) Android adalah sistem operasi (OS) -bersifat open source (terbuka)- yang dimiliki oleh Google Inc. Pada awal peluncuran, Android hanya digunakan pada perangkat mobile, yaitu telpon seluler. Namun seiring perkembangannya, sejak Android 3.0 (Honeycomb) diluncurkan, sistem operasi Android resmi digunakan dalam computer tablet.

\section{c. Global Positioning System (GPS)}

Menurut Bramantiyo Ahmed El-Rabbany dalam bukunya yang berjudul Introduction to GPS The Global Positioning System(p1), Global Positioning System(GPS) adalah sistem navigasi berbasis satelit yang dikembangkan oleh AS Departemen Pertahanan (DoD) di awal 1970-an. Awalnya, GPS dikembangkan sebagai sistem militer untuk memenuhi kebutuhan militer AS. Namun, kemudian itu dibuat tersedia untuk warga sipil, dan sekarang menjadi sistem dual-use yang dapat diakses oleh pengguna militer dan sipil. GPS memberikan posisi dan waktu informasi terus menerus, di mana saja di dunia, di bawah setiap kondisi cuaca. Karena melayani jumlah yang tidak terbatas karena jumlah pengguna yang semakin membengkak sebagai alasan keamanan GPS mulai one-way-ranging system (pasif). Artinya, pengguna hanya dapat menerima sinyal satelit.

\section{d. Peta}

Peta merupakan gambaran wilayah geografis, bagian permukaan bumi yang disajikan dalam berbagai cara yang berbeda, mulai dari peta konvensional yang tercetak hingga peta digital yang tampil di layar komputer. Peta dapat digambarkan dengan berbagai gaya, masing - masing menunjukkan permukaan yang berbeda untuk subjek yang sama untuk menvisualisasikan dunia dengan mudah, informatif dan fungsional.

Peta berbasis komputer (digital) lebih serba guna dan dinamis karena bisa menunjukkan banyak view yang berbeda dengan subjek yang sama. Peta ini juga memungkinkan perubahan skala, animasi gabungan, gambar, suara, dan bisa 
terhubung ke sumber informasi tambahan melalui internet. Peta digital dapat diupdate ke peta tematik baru dan bisa menambahkan detail informasi geografi lainnya (Carter dan Agtrisari, sebagai mana dikutip dari Santoso, 2016). 


\section{TUJUAN DAN MANFAAT PENELITIAN}

Pada bagian ini akan dijelaskan tujuan peneltian dan manfaat penelitian ini yaitu:

\subsection{Tujuan Penelitian}

Tujuan dari penilitian ini adalah:

a. Meneliti hasil penerapan $L B S$ yang digunakan pada Android

b. Meneliti cara kerja $L B S$ pada aplikasi yang dirancang didalam jurnal.

\subsection{Manfaat Penelitian}

Adapun manfaat dari penelitian ini adalah sebagai berikut.

a. Manfaat Kebijakan pada penilitian ini adalah diharapkan dapat membantu masyarakat atau pengguna smartphone untuk memperoleh informasi suatu lokasi atau object kapanpun dan dimanapun

b. Manfaat Teoritis pada penilitian ini adalah diharapkan penelitian ini dapat dijadikan panduan atau refrensi untuk penelitian selanjutnya dan menambah wawasan bagi pembaca. 


\section{METODOLOGI PENELITIAN}

Pada Metodologi Penelitian ini akan dikemukakan Jenis Penelitian, dan Metode Pengumpulan Data.

\subsection{Jenis Penelitian}

Jenis penelitian yang digunakan penulis adalah penelitian deskriptif dengan cara mengumpulkan informasi aktual secara rinci yang melukiskan gejala yang ada, mengindetifikasi masalah atau memeriksa kondisi dan praktek-praktek yang berlaku, membuat perbandingan atau evaluasi dan menetukan apa yang dilakukan orang lain dalam menghadapi masalah yang sama dan belajar dari pengalaman mereka untuk menetapkan rencana dan keputusan pada waktu yang akan datang.

\subsection{Metode Pengumpulan Data}

Metode pengumpulan data yang digunakan penulis dalam penelitian ini yaitu studi kepustakaan adalah dengan cara mempelajari literatur untuk mengumpulkan landasan teori kegiatan yang dilakukan penulis yaitu membaca, mencatat, dan mempelajari referensi dari jurnal dan buku yang membahas tentang pencarian lokasi dengan menggunakan Location Based Service (LBS). Data yang telah didapatkan akan digunakan sebagai acuan unruk membuat analisa penelitian berikutnya. 


\section{HASIL DAN PEMBAHASAN}

Pada penelitian ini menganalisis keempat jurnal dengan metode kasus yang berbeda namun menggunakan metode yang sama yaitu metode Location Based Service (LBS). Berikut hasil dan pembahasan keempat jurnal yang telah dianalisis.

\subsection{Hasil}

Hasil analisis pada keempat jurnal sebagai berikut:

a. Perancangan Aplikasi Location Based Service Rumah Sakit Yogyakarta pada Android Jurnal Seminar Nasional Informatika 2013 (semnasIF 2013) ISSN: 1979-2328 UPN “V e ter a n" Yogyakarta, 18 Mei 2013 jurnal yang ditulis oleh Ragil Tri Dianti Putri, dkk.

Jurnal ini memiliki kasus yaitu warga/ masyarakat Yogyakarta yang masih kurang mengetahui informasi letak rumah sakit di Yogyakarta sebagai tempat pelayanan dan fasilitas kesehatan dari masalah tersebut maka dirancang aplikasi yang dapat menunjukan lokasi rumah sakit yang dapat diakses kapan saja dan dimana saja menggunakan metode LBS. Aplikasi Location Based Service rumah sakit Yogyakarta pada Android merupakan aplikasi yang dibuat untuk membantu pengguna mengetahui informasi tempat-tempat rumah sakit di Yogyakarta. Informasi yang diberikan kepada pengguna adalah info umum tentang tempat yang dicari, peta lokasi tempat, jarak dan rute tempat yang dicari. Melalui smartphone berbasis Android pengguna aplikasi LBS akan berinteraksi menggunakan tampilan GUI agar memudahkan pengguna dalam mengoperasikan aplikasi.

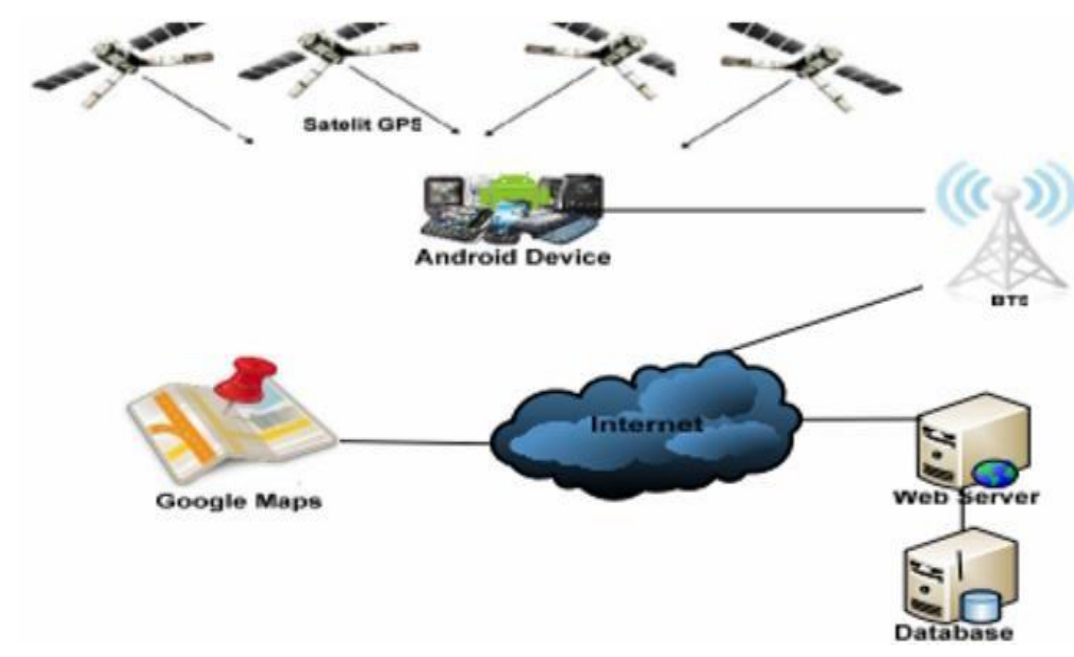

Gambar 2 Arsitektur Aplikasi LBS Rumah Sakit 
Aplikasi ini dibangun dengan konsep Client-Server. Pengguna yang mengakses sistem ini akan mengakses data yang terdapat pada webserver, selanjutnya informasi yang ditampilkan diambil dari alam Database demikian juga data yang diinputkan pengguna akan disimpan dalam Database, sehingga jika ada pencarian data, maka data yang diinginkan akan dicari ke database server yang selanjutnya dikirimkan ke client yang memesan data.

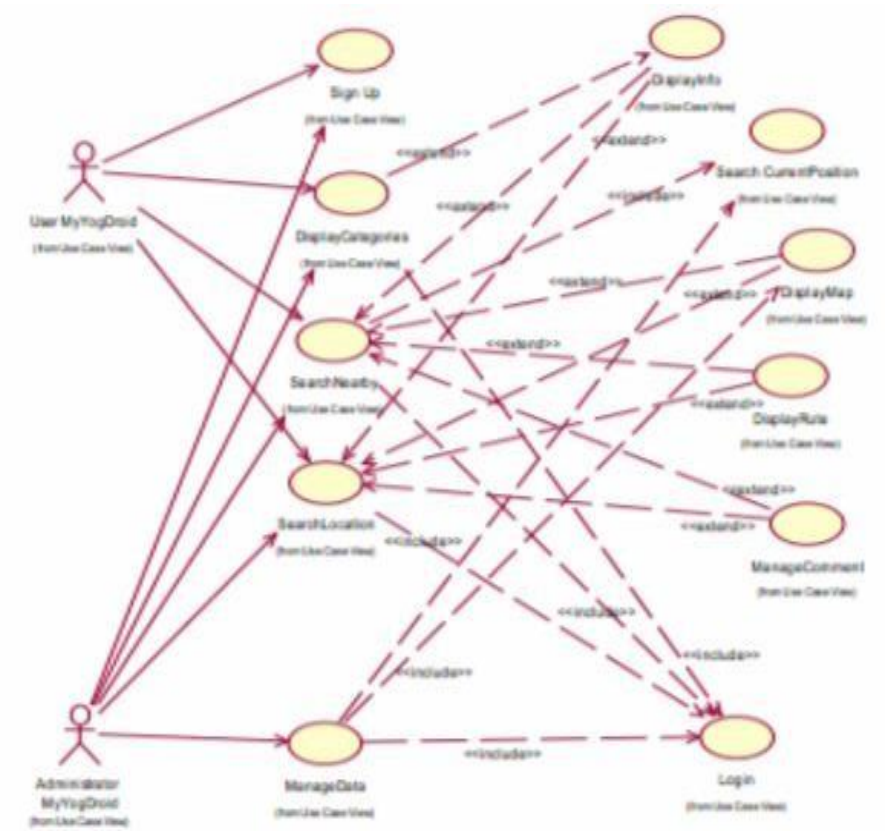

Gambar 3 Usecase Aplikasi LBS Rumah Sakit Yogyakarta Pada Android

Kebutuhan fungsionalitas perangkat lunak yang ada dalam aplikasi Location Based Service $(L B S)$ rumah sakit Yogyakarta pada Android dapat dilihat pada Gambar 3.

\section{1) Fungsi Login}

Fungsi Login merupakan fungsi yang digunakan oleh admin untuk dapat masuk dalam sistem yang akan digunakan.

\section{2) Fungsi Sign Up}

Merupakan fungsi yang digunakan untuk membuat account baru. Melalui antar muka pengguna dapat mengisikan data-data pribadinya untuk dapat memiliki akses masuk kedalam sistem sebagai pengguna biasa. Setelah pengguna menyelesaikan pembuatan account barulah pengguna dapat masuk dan mengakses layanan. 


\section{3) Fungsi Display Categories}

Merupakan fungsi yang digunakan untuk menampilkan kategori tempat rumah sakit yang ada dalam data base dalam bentuk List Category.

\section{4) Fungsi Search Nearby}

Merupakan fungsi yang digunakan untuk pencarian lokasi rumah sakit terdekat dalam radius 1 Kilometer dengan keberadaan pengguna yang ditampilkan dalam bentuk List Location.

\section{5) Fungsi Search Location}

Merupakan fungsi yang digunakan untuk mencari dan menampilkan daftar namanama lokasi rumah sakit yang sudah tersimpan dalam Database. Hasil pencarian ditampilkan berdasarkan inputan nama lokasi rumah sakit.

\section{6) Fungsi Manage Data}

Merupakan fungsi yang digunakan oleh admin untuk melakukan penyimpanan lokasi beserta informasi keberadaan lokasi rumah sakit baru yang dipilih admin untuk dimasukan dalam database.

\section{7) Rancangan Antarmuka Menu}

Rancangan antarmuka menu merupakan menu utama mengenai rumah sakit, terdapat 3 pilihan menu, yaitu Rumah sakit Umum, Rumah sakit Khusus dan Rumah sakit Daerah. Ketika salah satu menu dipilih maka akan menampilkan submenu yang berisi tentang informasi rumah sakit yang di pilih.

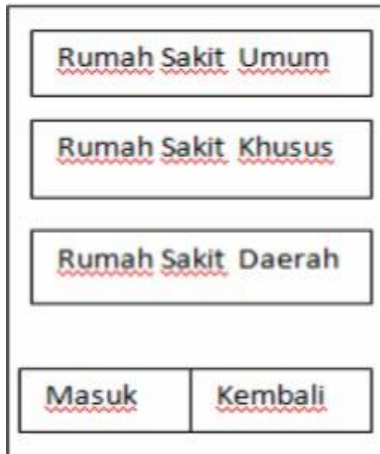

Gambar 4 Rancangan Antar Muka Sub Menu 


\section{8) Rancangan Antarmuka Sub Menu}

Rancangan antar muka submenu terdapat list rumah sakit yang bisa dipilih oleh user, ketika salah satu list dipilih maka akan tampil rumah sakit yang dipilih, dalam antarmuka submenu ini terdapat menu info Umum, Peta, Jarak, Rute, komentar dan Galeri Foto.

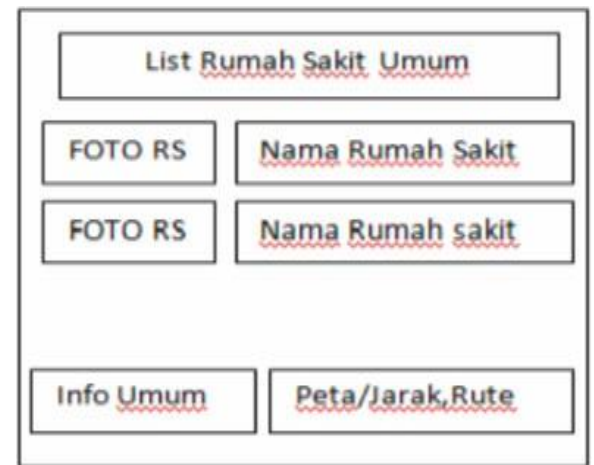

Gambar 5 Rancangan Antarmuka Submenu Antarmuka Peta dan

\section{9) Rancangan Antarmuka Peta}

Rancangan antarmuka peta ini menampilkan peta yang diakses dari google maps dimana dapat menunjukkan lokasi pengguna. Rancang antarmuka jarak dan rute menampilkan informasi peta dari Google maps untuk menunjukkan rute navigasi dari posisi pengguna hingga posisi lokasi yang dituju.

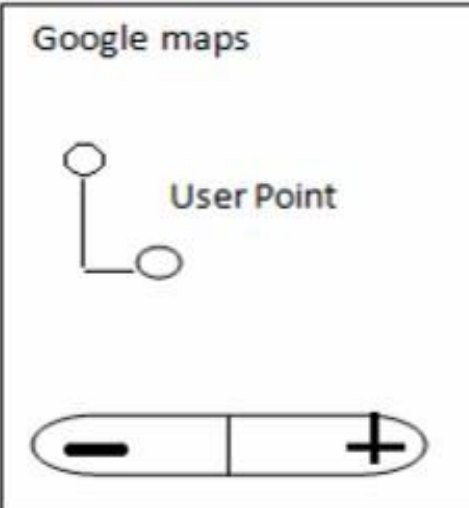

Gambar 6 Rancangan Antarmuka Peta 
b. Aplikasi Pencarian Rute Perguruan Tinggi Berbasis Android Menggunakan Location Based Service (LBS) di Kota Semarang

Jurnal ini merupakan Jurnal Teknologi dan Sistem Komputer (JTsiskom 2015) Vol.3, No.2, April 2015 e-ISSN: 2338-0403, Jurnal ini ditulis oleh Satriaji Cahyo Nugroho dkk. Jurnal ini memiliki kasus yaitu banyak calon mahasiswa di Semarang yang belum mengetahui mengenai informasi letak posisi perguruan tinggi tersebut Maka dari itu dibuatlah aplikasi sistem informasi lokasi perguruan tinggi menggunakan LBS untuk menentukan rute/jalur menuju ke perguruan tinggi. Alur perancangan sistem digambarkan menggunakan diagram alir (flowchart) di mana pada diagram alir digambarkan mengenai tahapan-tahapan dalam perancangan sistem serta penjelasan.

Mengenai proses perancangan sistem seperti ditunjukkan pada Gambar 7.

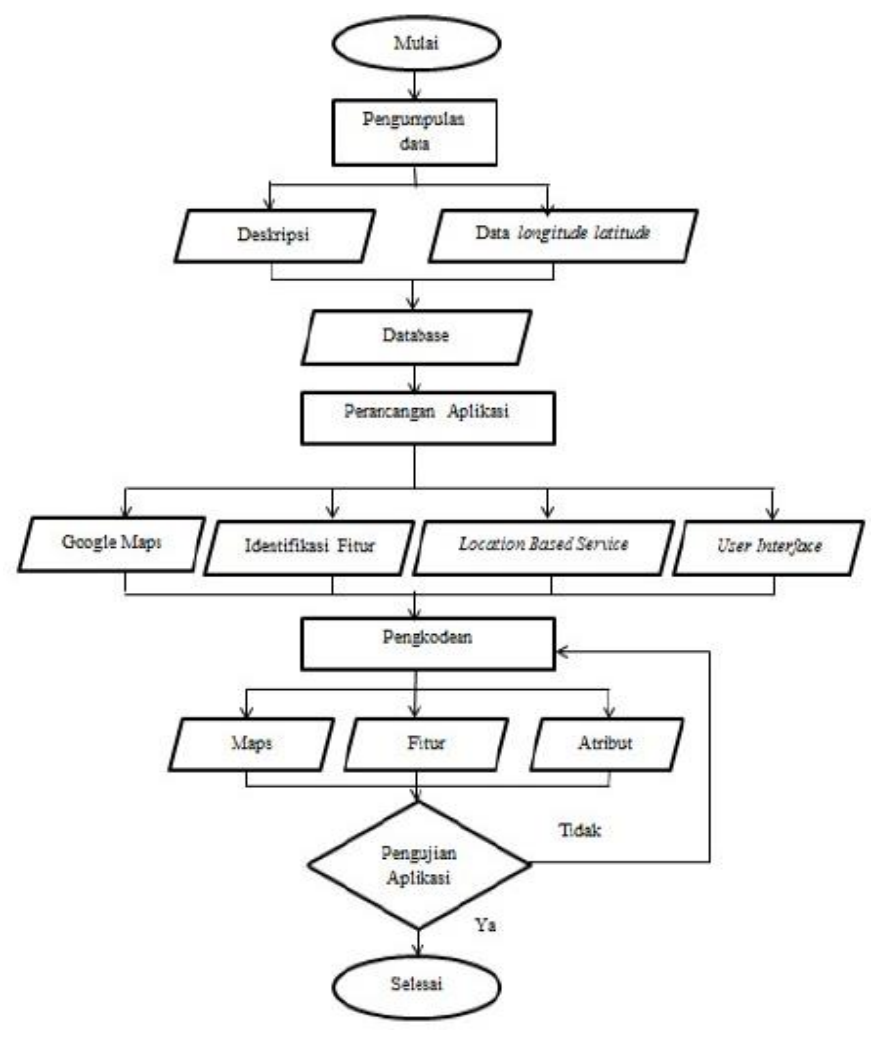

Gambar 7 Alur Perancangan Sistem 
Alur perancangan sistem pada Gambar 7 memiliki tiga proses utama yaitu proses pengumpulan data, proses perancangan aplikasi dan proses pengkodean. Dalam proses pengumpulan data, data yang dibutuhkan adalah data-data deskripsi perguruan tinggi seperti informasi alamat, nomor telepon, sejarah, visi-misi, dan juga data logitude latitude yang digunakan sebagai koordinat yang dibutuhkan dalam penentuan posisi lokasi perguruan tinggi di mana data-data yang telah diperoleh dimasukkan dan disimpan dalam database. Proses perancangan aplikasi pada pembuatan aplikasi rute perguruan tinggi LBS meliputi perancangan fiturfitur yang akan diimplementasikan dalam aplikasi, user interface, Google Maps dan penerapan Location Based Service (LBS). Proses terakhir adalah proses pengkodean di mana data-data yang telah disimpan dan aplikasi yang telah dirancang akan dibuat menjadi aplikasi yang dapat dijalankan dan diimplementasikan pada perangkat mobile sehingga dapat digunakan secara langsung oleh user.

Terdapat dua jenis kebutuhan dalam pembuatan aplikasi pencarian rute perguruan tinggi LBS yaitu kebutuhan fungsional dan non fungsional. Kebutuhan fungsional mendeskripsikan kemampuan dan layanan dari sebuah sistem. Kebutuhan fungsional dalam perancangan sistem adalah sebagai berikut:

1) Aplikasi dapat mengetahui koordinat lokasi saat ini menggunakan GPS pada perangkat Android sehingga memudahkan user dalam mengetahui informasi keberadaan posisi user saat itu juga.

2) Aplikasi dapat menampilkan list daftar perguruan tinggi di mana dalam daftar tersebut berisikan data deskripsi mengenai masing-masing perguruan tinggi serta beberapa fitur seperti fitur galeri, link video, dan nomor telepon tiap perguruan tinggi sehingga memudahkan user dalam mendapatkan informasi. Selain itu, dalam daftar perguruan tinggi juga terdapat akumulasi jarak dalam satuan kilometer $(\mathrm{km})$ dari koordinat posisi user. Terdapat fasisilitas rute yang dapat digunakan oleh pengguna untuk mengetahui rute tujuan yang akan dilalui dalam perjalanan menuju tiap-tiap perguruan tinggi. Selain rute utama, terdapat juga rute alternatif sehingga pengguna tidak hanya dapat 
menggunakan satu jalur saja tetapi dapat menggunakan jelur lain menuju lokasi perguruan tinggi tersebut.

3) Aplikasi dapat menampilakan rute yang dapat digunakan oleh user untuk mengetahui rute tujuan yang akan dilalui dalam perjalanan menuju tiaptiap perguruan tinggi.

4) Aplikasi dapat memberikan notifikasi suara (beep) pada jarak 250-meter dari tiap lokasi perguruan tinggi sebagai tanda bahwa lokasi tujuan sudah dekat dengan user.

Kebutuhann non-fungsional merupakan kebutuhan yang tidak langsung berhubungan dengan spesifik yang disediakan oleh sistem. Kebutuhan non fungsionalitas sistem adalah sebagai berikut:

1) Aplikasi ini dapat berjalan minimal pada sistem operasi Android Froyo.

2) Ukuran aplikasi di bawah $10 \mathrm{Mb}$.

3) Aplikasi harus terhubung ke internet untuk mendapatkan akses ke Google Maps.

Pada pemodelan UML digunakan usecase dan juga diagram aktivitas untuk mengetahui gambaran yang lebih jelas mengenai interaksi antara aktor dengan lingkungan sistem Terdapat dua usecase dalam pemodelan aplikasi pencarian rute perguruan tinggi LBS yaitu use case user dan use case administrator. Diagram use case user merupakan pemodelan dari kebutuhan fungsional yang dapat dilakukan user pada aplikasi seperti dapat melihat koordinat posisi, melihat daftar list perguruan tinggi, melihat rute perguruan tinggi dan mendapat notifikasi suara ketika telah dekat dengan lokasi perguruan tinggi seperti ditunjukkan pada Gambar 8. 


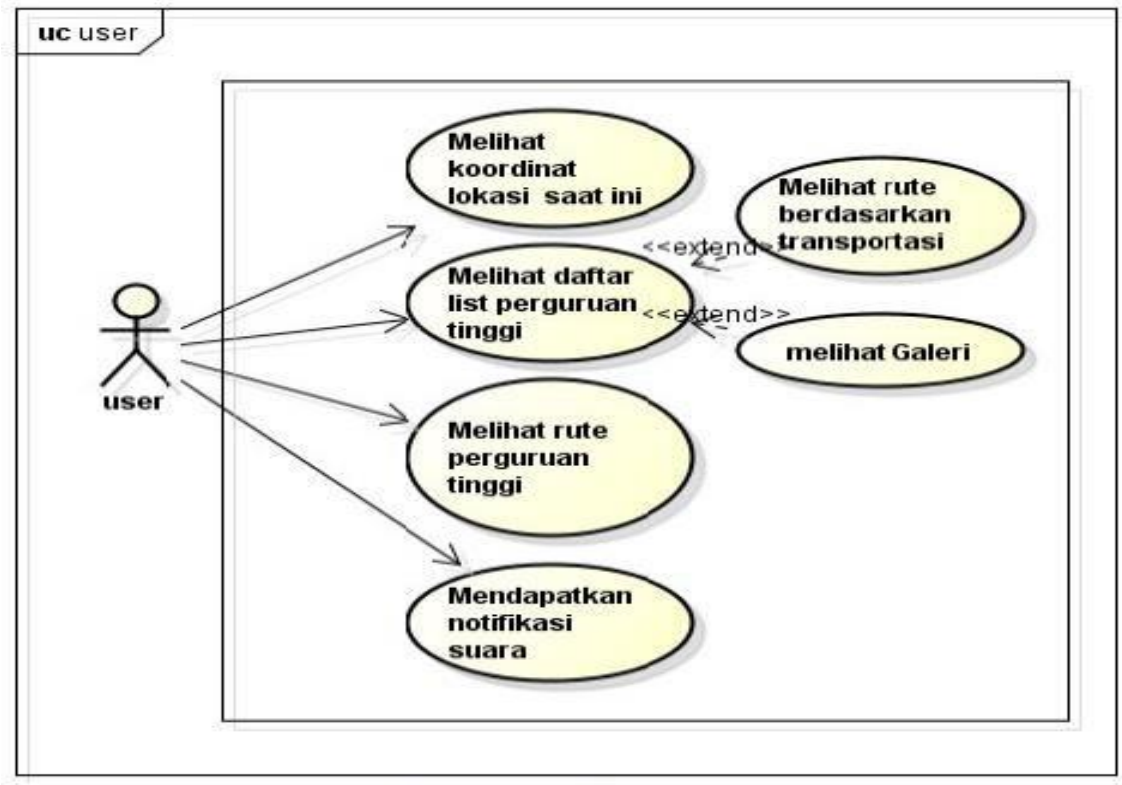

Gambar 8 Diagram Usecase User

Sedangkan administrator memiliki hak untuk melakukan login, menambah data, mengubah data dan menghapus data perguruan tinggi pada database server seperti ditunjukkan Gambar 9.

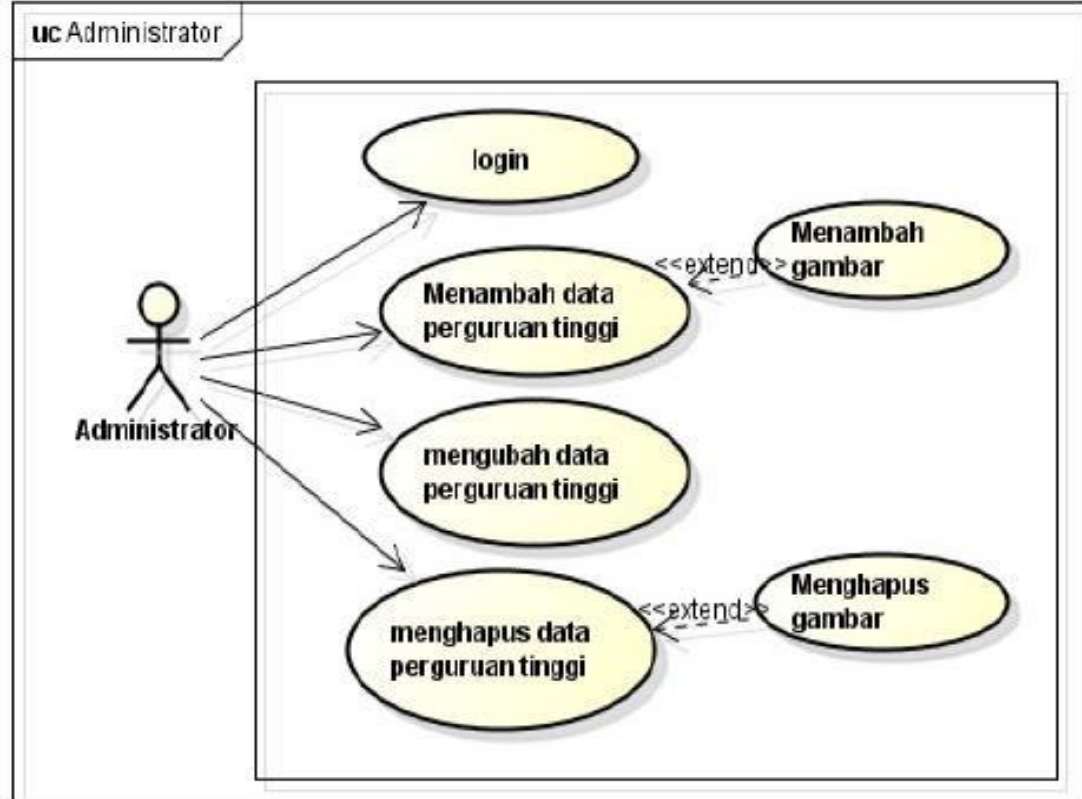

Gambar 9 Diagram Usecase Administrator 
Diagram aktivitas melihat koordinat posisi merupakan aktivitas yang terjadi ketika user memilih menu Posisiku. Aplikasi akan merespon dan menampilkan koordinat posisi user. Jika koneksi internet dan GPS tidak nyala maka akan terdapat notifikasi gagal atau error seperti Gambar 10.

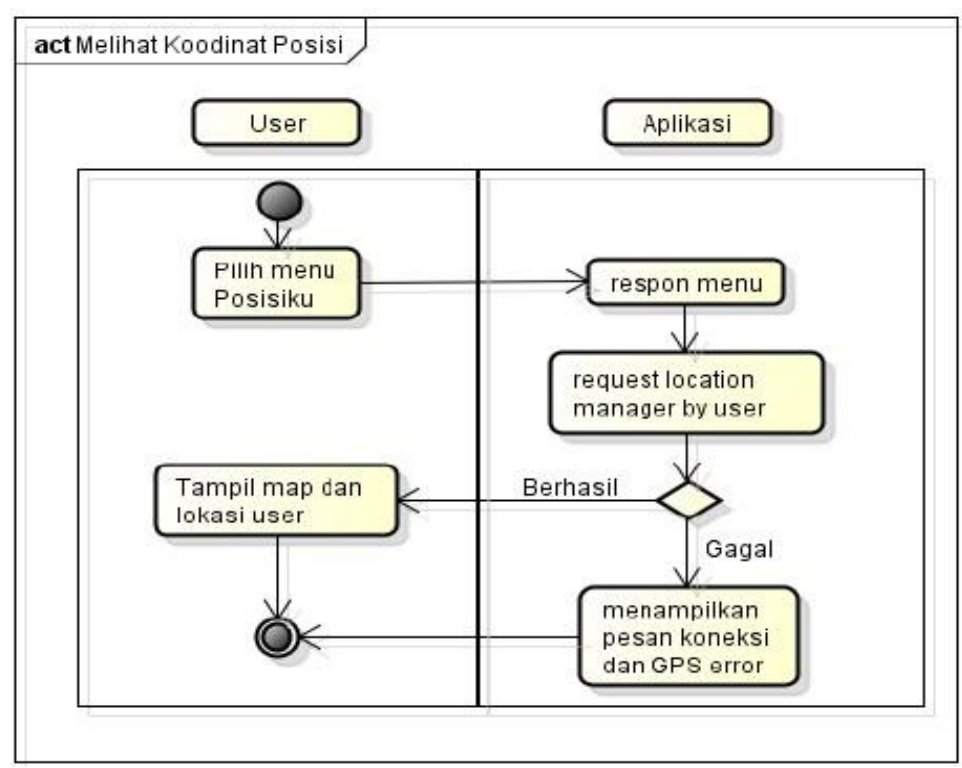

Gambar 10 Diagram Aktivitas Melihat Koordinat Posisi

Diagram aktivitas melihat daftar perguruan tinggi merupakan aktivitas ketika user memilih menu daftar perguruan tinggi. Ketika user memilih menu daftar perguruan tinggi, maka aplikasi akan merespon dan meampilkan list daftar perguruan tinggi yang ada di kota Semarang seperti ditunjukkan Gambar 11.

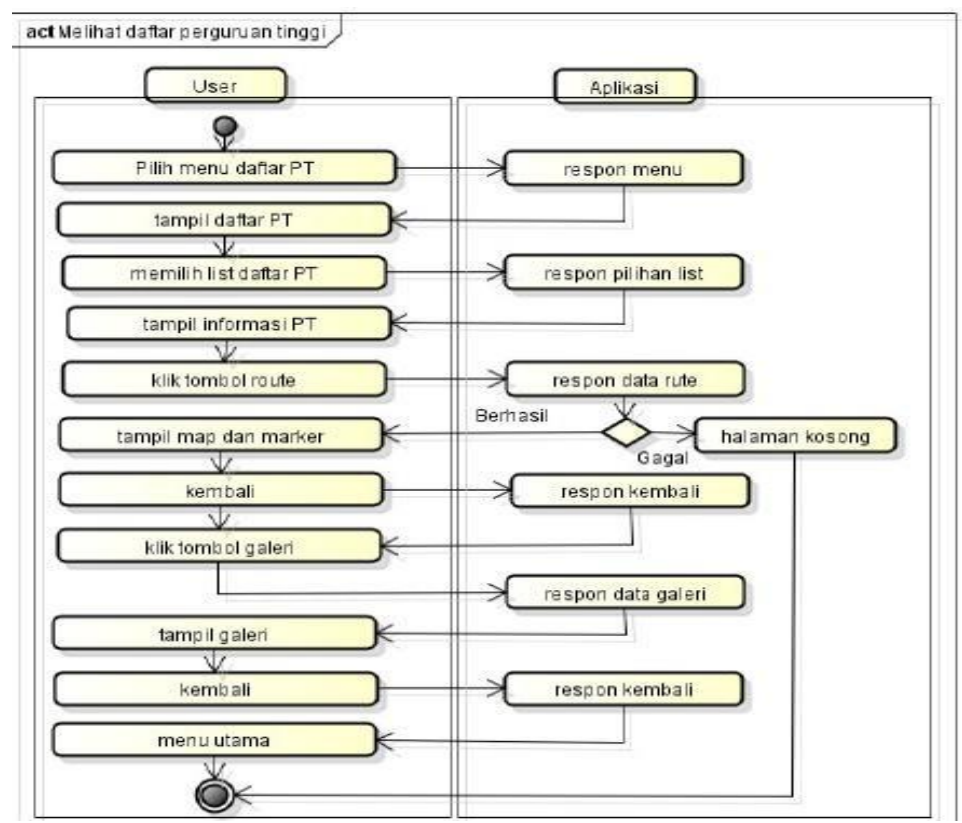

Gambar 11 Diagram Aktivitas Melihat Daftar Perguruan Tinggi 
Diagram aktivitas melihat lokasi-lokasi perguruan tinggi merupakan aktivitas ketika user memilih menu lokasi-lokasi perguruan tinggi di mana aplikasi akan merespon dan menampilkan letak perguruan-perguruan tinggi yang ada di kota Semarang seperti ditunjukkan Gambar 12.

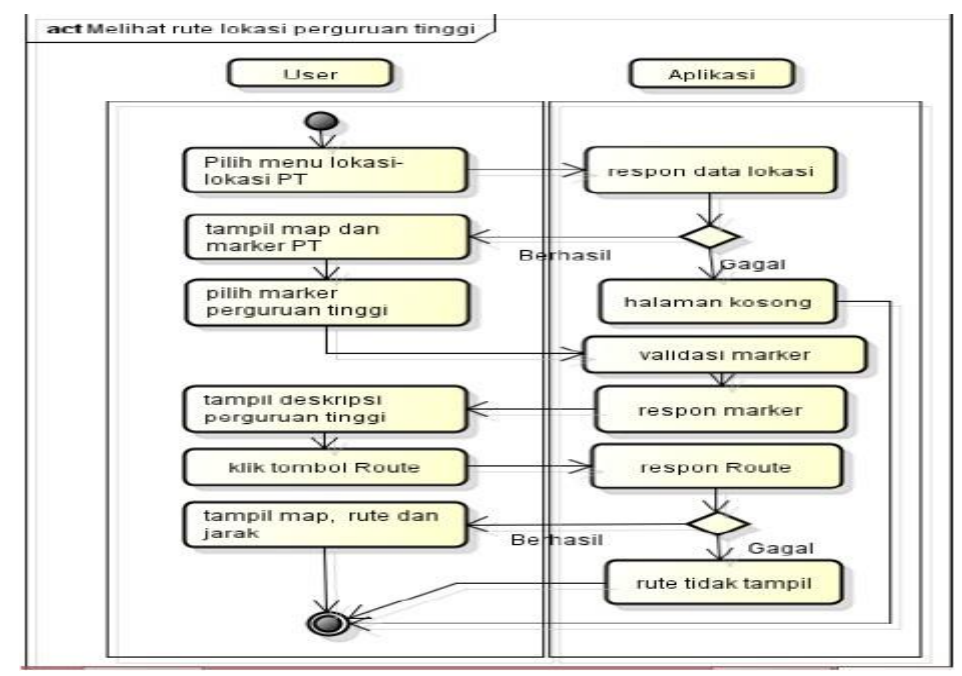

Gambar 12 Diagram Aktivitas Melihat Lokasi-Lokasi Perguruan Tinggi

Berikut ini merupakan tampilan hasil dari perancangan sistem yang telah dibuat:

1) Menu Posisiku merupakan menu dimana user dapat melihat posisi user saat ini.

2) Map yang digunakan adalah Map google. User dapat mencari universitas mana yang akan dituju dengan memasukkan keyword yang ada pada tombol "Cari" seperti ditunjukkan Gambar 13.

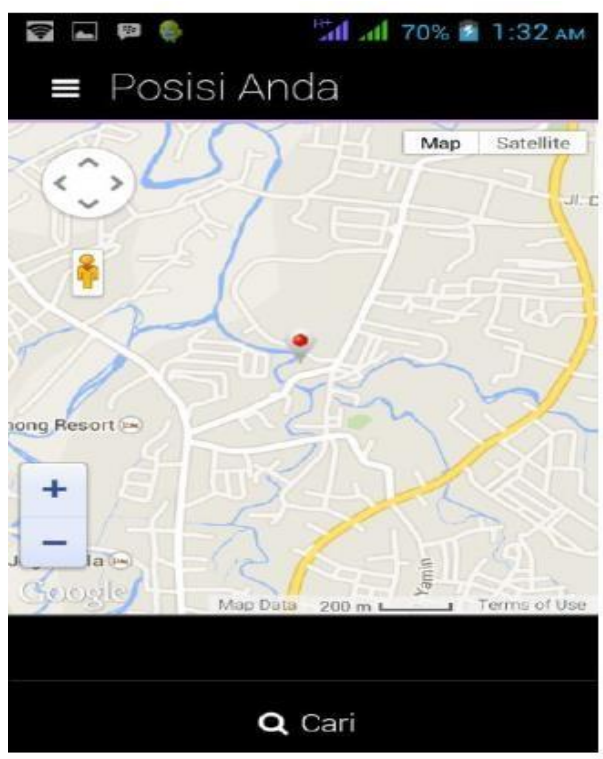

Gambar 13 Tampilan Posisiku 
c. Implementation of Location Base Service on Tourism Places in West Nusa Tenggara by using Smartphone

Jurnal ini merupakan International Journal of Advanced Computer Science and Applications (IJACSA), Vol. 6, No. 8, 2015 oleh Karya Gunawan dan Bambang Eka Purnama. Jurnal ini memiliki kasus yaitu Para wisatawan yang mengunjungi Nusa Tenggara Barat menggunakan GPS (Global Positioning System) pada Smartphone untuk mencari informasi lokasi wisata dan untuk menemukan jalur ke lokasi wisata. Sedangkan informasi dari situs pariwisata belum terdaftar di Google Maps. Hal ini menyebabkan wisatawan kesulitan dalam memperoleh informasi dan lokasi yang benar dan mengakibatkan kurangnya minat wisatawan untuk mengunjungi lokasi wisata di Lombok dan Sumbawa. Untuk memudahkan para wisatawan mendapatkan informasi yang valid tentang pariwisata Nusa Tenggara Barat perlu adanya aplikasi pencarian dan melacak lokasi tempat-tempat wisata, Aplikasi tempat wisata memberikan informasi seperti deskripsi dari pemandangan, alamat wisata, galeri foto, fasilitas yang tersedia dan jalur terdekat.

Berikut ini kebutuhan Hardware dan Software yang dibutuhkan dalam perancangan aplikasi. Server spesifikasi pembuatan aplikasi pariwisata berbasis Android menggunakan perangkat keras berikut:

1) Processor Intel Core i3-2367M @ $1.40 \mathrm{GHz}$

2) Graphics Cards nVidia Geforce GT 620M 1 GB

3) $R A M 4 G B D D R 3$

4) Display 14.1” WXGA Acer Crystal Brite LCD

5) Hard disk 500GB HDD

Spesifikasi Android yang dibutuhkan untuk menjalankan aplikasi parwisata pada perangkat Android sebagai berikut:

1) Handheld Samsung Galaxy A3

2) Operating System Android version 4.4 Kit Kat

3) CPU Quad-Core $1.2 \mathrm{GHz}$ Cortex-A53

4) Memory RAM $1 \mathrm{~GB}$

5) External Memory 16 GB 
Software Spesifikasi perangkat lunak yang digunakan untuk membuat aplikasi Pariwisata NTB adalah sebagai berikut:

1) Java Development Kit (JDK) 8u45-nb-8_0_2 Windows-x64

2) Android Software Development Kits (SDK)

3) Eclipse Kepler and ADT

4) Kies Samsung version 3

Rancangan Interface yang akan digunakan pada Aplikasi pariwisata NTB adalah sebagai berikut:

1) Menu Utama

Halaman ini adalah halaman yang akan muncul setelah splash screen. Halaman ini berisi daftar tempat wisata, paket wisata, dan berita Pariwisata Nusa Tenggara Barat. Setiap item yang dapat dipilih untuk menampilkan informasi rinci, galeri foto dan lokasi wisata seperti Google maps item, dapat dilihat pada Gambar 14.

\begin{tabular}{|c|c|c|c|}
\hline $\begin{array}{l}\text { Tempat } \\
\text { Wisata }\end{array}$ & $\begin{array}{l}\text { Paket } \\
\text { Wisata }\end{array}$ & Artikel & About \\
\hline & \multicolumn{2}{|c|}{$\begin{array}{l}\text { Nama Tempat Wisata } \\
\text { Daerah Tempat Wisata } \\
\text { Dipublikasi oleh }\end{array}$} & Tanggal Publikasi \\
\hline & \multicolumn{2}{|c|}{$\begin{array}{l}\text { Nama Tempat Wisata } \\
\text { Daerah Tempat Wisata } \\
\text { Dipublikasi oleh }\end{array}$} & Tanggal Publikasi \\
\hline & \multicolumn{2}{|c|}{$\begin{array}{l}\text { Nama Tempat Wisata } \\
\text { Daerah Tempat Wisata } \\
\text { Dipublikasi oleh }\end{array}$} & Tanggal Publikasi \\
\hline & \multicolumn{2}{|c|}{$\begin{array}{l}\text { Nama Tempat Wisata } \\
\text { Daerah Tempat Wisata } \\
\text { Dipublikasi oleh }\end{array}$} & Tanggal Publikasi \\
\hline & \multicolumn{2}{|c|}{$\begin{array}{l}\text { Nama Tempat Wisata } \\
\text { Daerah Tempat Wisata } \\
\text { Dipublikasi oleh }\end{array}$} & Tanggal Publikasi \\
\hline
\end{tabular}

Gambar 14 Tampilan Menu Utama

2) Informasi Detail Halaman

Halaman ini menampilkan informasi rinci tentang tempat-tempat wisata. Pada halaman ini, ada galeri menu foto, lokasi wisata dan berbagi informasi melalui media social, dapat dilihat pada Gambar 15. 


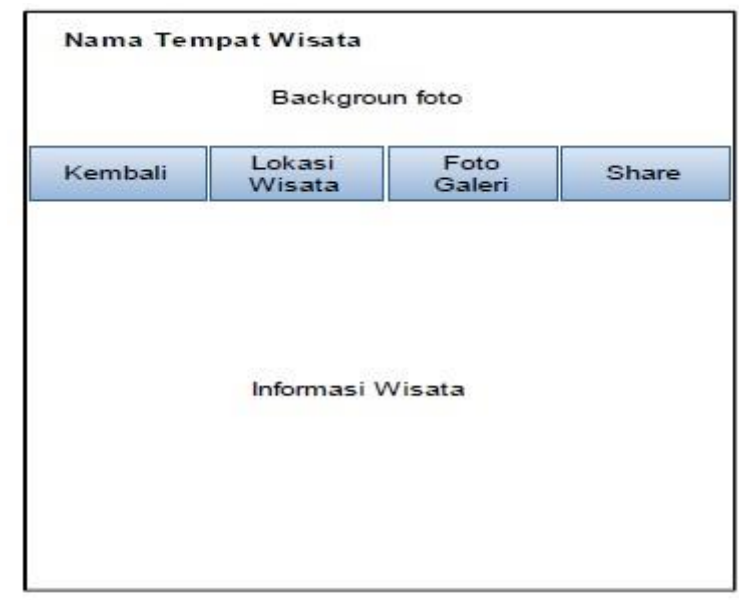

Gambar 15 Tampilan Halaman Infrormasi

3) Halaman Rute Pariwisata

Halaman rute pariwisata adalah halaman yang menunjukkan rute perjalanan atau rute jalur, yang menunjukan posisi user untuk menuju lokasi yang dituju, rancangan design dapat dilihat pada Gambar 16.

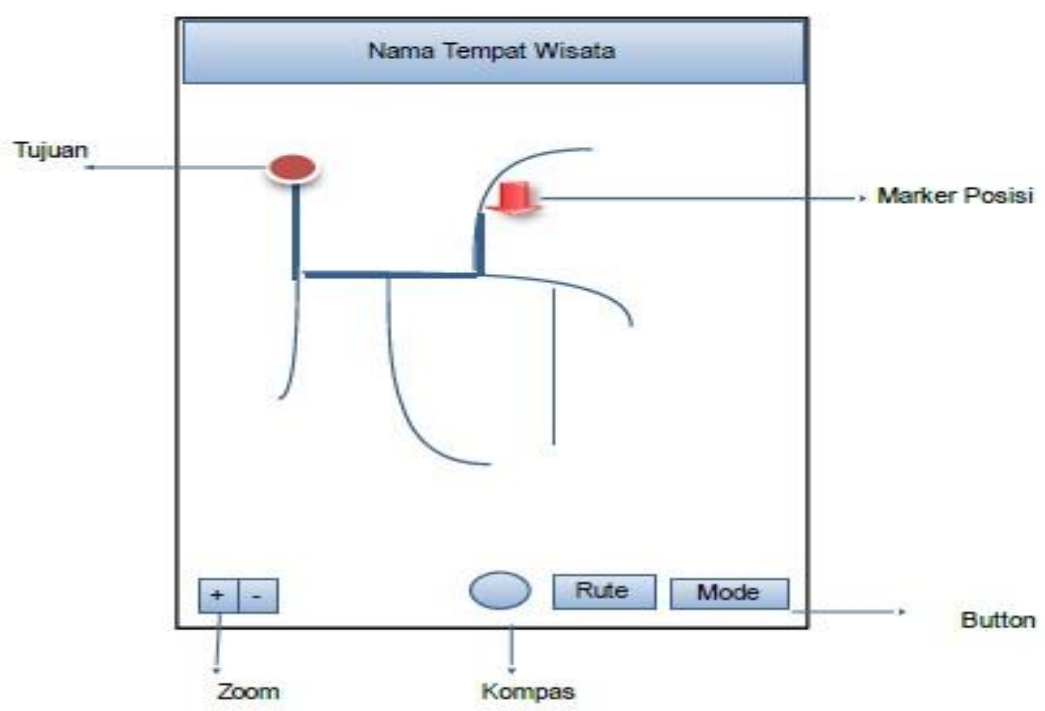

Gambar 16 Halaman Pencarian Rute Pariwisata

Aplikasi ini akan berjalan jika perangkat terhubung ke internet dan GPS untuk menentukan posisi turis atau aplikasi pengguna. Berikut ini adalah Hasil tampilan dari desain yang telah di Implementasikan pada Android. Halaman ini menampilkan informasi rinci tentang tempat-tempat wisata. Untuk melihat posisi atau pilih situs wisata sehingga akan menampilkan form posisi perjalanan Google Maps seperti Gambar 17. 


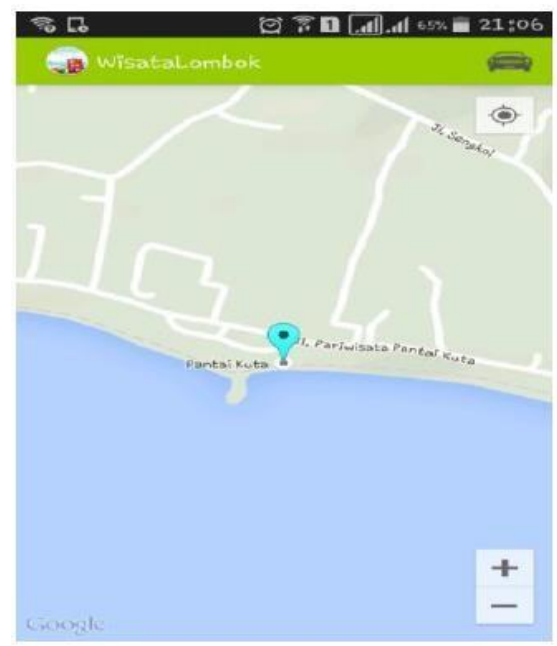

Gambar 17 Halaman Google Maps

Halaman ini hanya akan menampilkan Google Maps dari lokasi tempat wisata. Untuk melihat rute dari lokasi, klik penanda yang muncul lalu akan ada kesepakatan, jika ia ingin menggunakan Google Maps atau tidak dan pilihan memilih jalur terpendek atau jalur dengan waktu tempuh terpendek di Google maps sehingga akan menampilkan rute seperti yang ditunjukkan pada Gambar 18 .

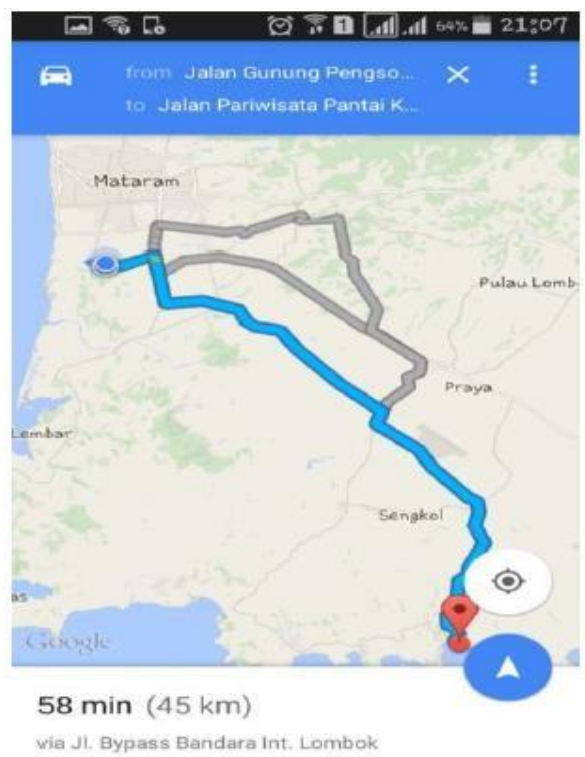

Gambar 18 Halaman Rute Pariwisata 
d. Providing Emergency Services Using Location Based Tracking on Mobile Devices

Jurnal ini merupakan International Journal of Science, Engineering and Technology Research (IJSETR), ISSN: 2278 - 7798, Volume 3, Issue 3, March 2014 oleh Ankita Deshpande, DevashishLokhande, Shrutika Vithalkar. Department of Computer Technology, YCCE Nagpur- 441110, Maharashtra, India. Jurnal ini memiliki kasus yaitu lambatnya pencarian seseorang yang sedang dalam keadaan darurat sehingga seringkali korban sulit untuk dapat ditolong Oleh karna itu Aplikasi ini bermaksud untuk meningkatkan efektivitas dan efisiensi dengan respon lebih cepat dan juga memberikan bantuan selama bencana.

Aplikasi ini menggunakan metode LBS. Metode ini tergantung pada pendekatan yang digunakan. Lokasi dapat direpresentasikan dalam hal tata ruang atau sebagai deskripsi teks. Untuk menemukan posisi mobile, LBS menggunakan metode penentuan posisi secara real time. Dibawah ini merupakan rancangan interface aplikasi yang didapat untuk melacak keadaan darurat menggunakan metode LBS.

\section{1) Form Registrasi}

Pada form ini user diwajibkan untuk mengisi data berupa nama, email dan password untuk daftar ke aplikasi tersebut dan data yang dimasukan akan otomatis tersimpan pada database, form registrasi dapat dilihat pada Gambar 19.

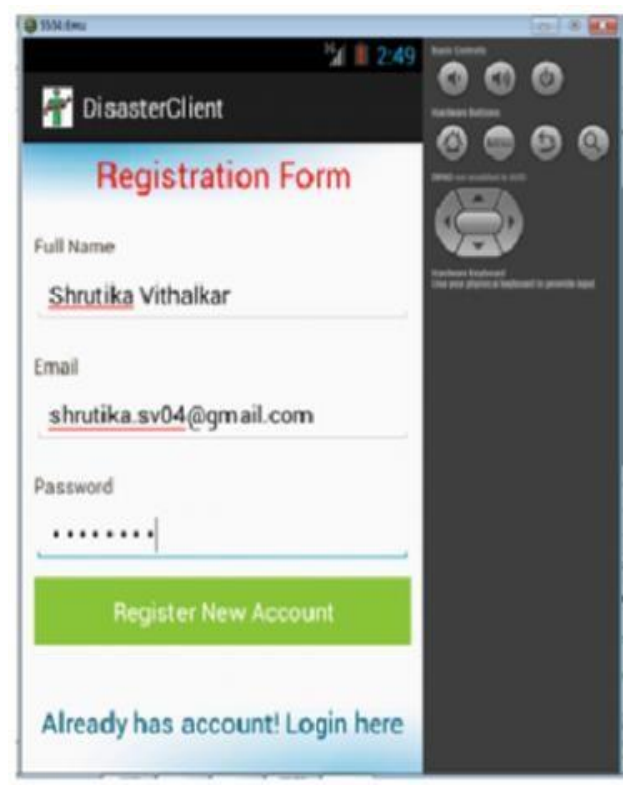

Gambar 19 Form Registrasi 


\section{2) Form Login}

Setelah user mendaftar maka akan tampil form login untuk masuk ke aplikasi seperti Gambar 20.

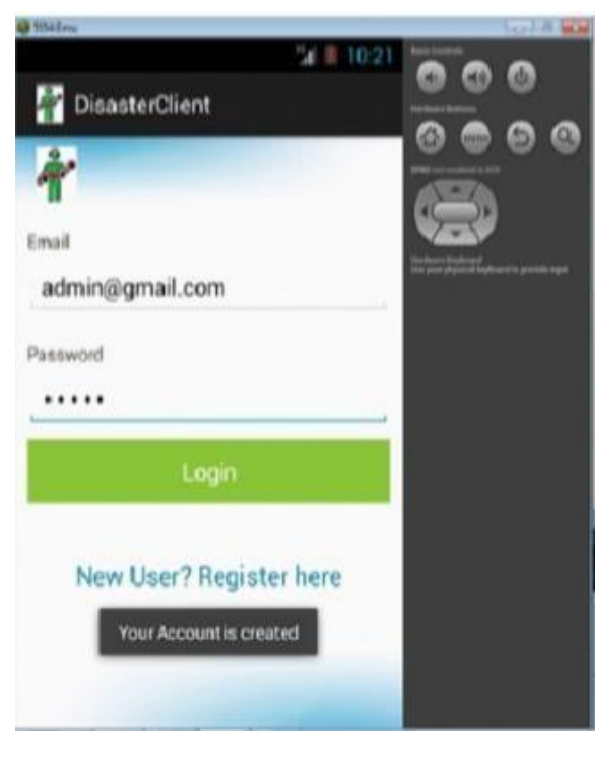

Gambar 20 Form Login

\section{3) Menu Chat}

Setelah berhasil login, User dapat masuk ke aplikasi dan bisa menyiarkan pesan kepada tim penyelamat dan meminta bantuan. Selain chatting, lokasi orang yang terperangkap akan ditambahkan di tim editor.Rescue chatting dapat melihat lokasi orang tersebut dan memberikan bantuan, Berikut adalah contoh obrolan antara user dan client dapat dilihat pada Gambar 21.

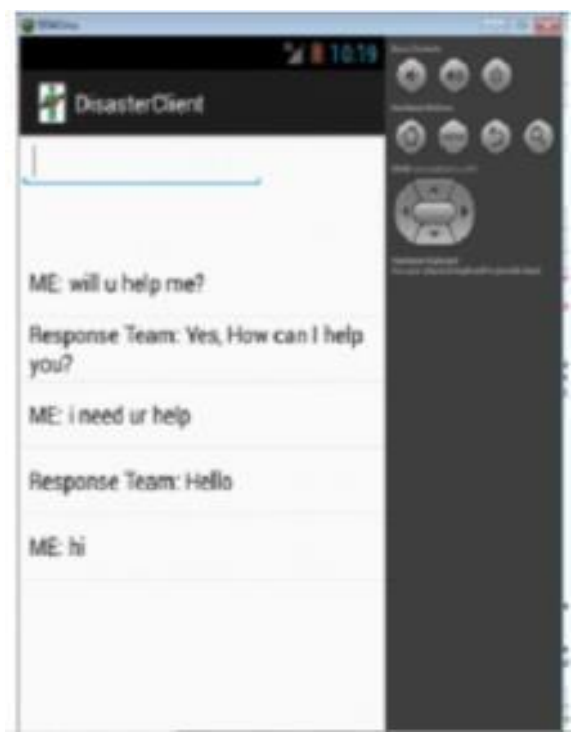

Gambar 21 Menu Chat 


\subsection{Pembahasan}

Berdasarkan hasil yang telah diuraikan dari keempat jurnal yang berisi kasus serta hasil implementasi pada aplikasi LBS yang berbeda, Penulis dapat menganalisis bahwa keempat jurnal ini memiliki tahapan perancangan aplikasi, kelebihan dan kekurangan yang berbeda, tahapan perancangan aplikasi, kekurangan dan kelebihan pada jurnal ini dapat dilihat sebagai berikut.

a. Jurnal Perancangan Aplikasi Location Based Service Rumah Sakit Yogyakarta pada Android.

Pada jurnal ini aplikasi dibangun menggunakan konsep client server, yaitu Pengguna sistem mengakses data yang terdapat pada webserver, lalu Informasi yang ditampilkan diambil dari dalam database service dan data yang diinput juga akan disimpan kedalam database, Sehingga pencarian data akan dicari didalam database server lalu dikirimkan keclient yang merequest data.

Kelebihan: pada jurnal ini menampilkan hasil rancangan interface aplikasi yang cukup jelas dan mudah dimengerti.

Kekurangan: pada jurnal ini tidak ada penjelasan mengenai tahapan-tahapan dalam proses perancangan sistem aplikasi secara detail sehingga pembaca sulit memahami langkah dari perancangan sistem aplikasi tersebut.

b. Aplikasi Pencarian Rute Perguruan Tinggi Berbasis Android Menggunakan Location Based Service (LBS) di Kota Semarang.

Alur perancangan sistem pada jurnal ini memiliki tiga proses utama yaitu:

1) Proses pengumpulan data untuk dimasukan dan disimpan didalam database

2) Proses perancangan aplikasi pada pembuatan aplikasi rute perguruan tinggi

3) Proses pengkodean untuk menjalankan aplikasi dan diimplementasikan pada perangkat mobile.

Kelebihan: pada jurnal ini tahap perancangan sistem ditampilkan dengan detail dan menampilkan secara rinci rancangan interface aplikasi. 
Kekurangan: pada jurnal ini aplikasi yang dirancang hanya dapat berjalan minimal pada sistem operasi Android dan aplikasi harus terhubung ke internet untuk mendapatkan akses ke Google Maps.

c. Jurnal Implementation of Location Based Service on Tourism Places in West Nusa Tenggara by Using Smartphone.

Langkah-langkah pengembangan sistem pada aplikasi ini adalah.

1) Studi literature

2) Mengumpulkan data primer dan sekunder

3) Mengembangkan algoritma dan menentukan fitur yang disediakan oleh aplikasi yang berjalan di kedua sisi klien dan sisi server juga merancang basis data.

4) Menulis Program pada Client dan Server

5) Performing aplikasi pengujian sistem di kedua sisi client dan sisi server.

Kelebihan: pada jurnal ini menampilkan spesifikasi hardware, software, rancangan interface serta hasil tampilan dari desain yang telah diimplementasikan pada Android dengan sangat rinci.

Kekurangan: pada jurnal ini tidak menampilkan tahap proses perancangan sehingga pembaca kesulitan dalam mengetahui tahap-tahap proses perancangan.

d. Jurnal Providing Emergency Services Using Location Based Tracking on Mobile Devices.

Langkah-Langkah perancangan sistem:

1) Klien mengirimkan permintaan penggunaan dan memasukan lokasi geografis dari perangkat mobile untuk server.

2) Server bertanggung jawab untuk menyediakan layanan berdasarkan lokasi geografis perangkat mobile Android dengan mengumpulkan data di lapangan seperti bujur, lintang, dan ketinggian yang dibuat oleh Klien. 
3) Server akan menempatkan informasi yang dikumpulkan dari lapangan ke dalam database dan kemudian akan memberikan layanan untuk semua klien berdasarkan database.

4) Data yang telah dimasukan kedalam database akan secara otomatis tersambung dengan tim penyelamat.

Kelebihan: pada jurnal ini menampilkan rancangan interface dengan jelas sehingga mudah dipahami.

Kekurangan: tidak d i j e l a s k a n secara detail proses perancangan aplikasi sehingga pembaca sulit memahami.

Dari keempat jurnal yang telah penulis uraikan tahapan, kelebihan, serta kekurangannya, penulis amati bahwa pada empat jurnal tersebut diantaranya memiliki jurnal terbaik yaitu Jurnal Aplikasi Pencarian Rute Perguruan Tinggi Berbasis Android Menggunakan Location Based Service (LBS) di Kota Semarang Karena jurnal tersebut memaparkan langkah proses perancangan sistem dengan jelas dan mudah dipahami serta hasil nya menampilkan interface aplikasi dengan sangat rinci.

Serta jurnal yang tidak memenuhi tahapan metode LBS ditunjukkan pada jurnal Providing emergency services using location-based tracking on mobile devices Karena pada jurnal ini, tidak memaparkan proses perancangan dengan jelas dan pada hasil tidak menampilkan interface dengan jelas. 


\section{RENCANA PENELITIAN BERIKUTNYA}

Penulisan ilmiah ini diambil guna untuk menulis Tugas Akhir, maka dari itu penulis berencana pada tugas akhir nanti penelitian pada aplikasi Location Based Service yang saat ini hanya sebatas analisa saja mampu dikembangkan lagi kedalam sebuah aplikasi yang dapat digunakan untuk mencari tambal ban terdekat dan dapat melihat status tambal ban tersebut, alasan penulis membuat penulisan ini karena belum ada aplikasi yang dapat menunjukan lokasi tambal ban terdekat dengan menggunakan metode Location Based Service, diharapkan dengan adanya aplikasi ini dapat membantu warga yang sedang mencari tambal ban lalu penulis berencana menerapkannya pada kota Bandar Lampung, sehingga penelitian ini dapat berguna bagi masyarakat luas khususnya warga Bandar Lampung sendiri.

\section{PROBLEM \\ - Masyarakat yang sedang dalam perjalanan \\ dan mengalami pecah ban sering kali \\ kesulitan dalam mencari tambal ban terdekat terutama malam hari.}

SOLUTION

- Merancang aplikasi yang dapat menunjukan lokasi dan status tambal ban yang terdekat.

\section{APPROUCH}

- Aplikasi pencarian lokasi dan status tambal ban terdekat dengan menggunakan metode LBS

RESULT

- Menghasilkan aplikasi LBS yang dapat

membantu untuk mengetahui lokasi tambal

ban yang paling dekat dengan user dan dapat

melihat status tambal ban tersebut.

Gambar 22 Kerangka Berpikir Rencana Penelitian Berikutnya 


\section{KESIMPULAN DAN SARAN}

Pada bagian ini akan dikemukakan kesimpulan dan saran penelitian yaitu:

\subsection{Kesimpulan}

Dari hasil penelitian yang telah dilakukan terhadap keempat jurnal tersebut bahwa Location Based Service (LBS) dapat diterapkan pada banyak objek. Adapun kesimpulan yang didapatkan dalam penulisan ini adalah:

a. Dari keempat jurnal yang penulis teliti, dapat diperoleh kesimpulan bahwa jurnal yang memaparkan perancangan dengan penerapan metode Location Based Service pada aplikasi dengan jelas dan mudah untuk dipahami serta memberikan rancangan interface secara detail adalah jurnal Aplikasi Pencarian Rute Perguruan Tinggi Berbasis Android Menggunakan Location Based Service (LBS) di Kota Semarang.

b. Dengan perancangan aplikasi menggunakan metode Location Based Service $(L B S)$, dapat membantu kita dalam menampilkan posisi kita saat ini secara geografis yang didapat dari perangkat bergerak atau smartphone yang kita bawa dan dapat berfungsi sebagai alat penunjuk lokasi sehingga dapat mempermudah kita dalam mencari sebuah lokasi atau objek yang dituju.

\subsection{Saran}

Saran untuk penelitian selanjutnya diharapkan metode LBS ini dapat dikembangkan dan diimplementasikan kedalam aplikasi dengan objek yang berbeda sehingga dapat membantu dalam mencari lokasi yang diinginkan. 


\section{DAFTAR PUSTAKA}

Bramantiyo Ahmed El-Rabbany. (2002). Introduction to GPS the Global Positioning System. Halaman 1

Erlangga, E., \& Furqon, A. (2014). Portal e-Brosur Berbasis Modern Advertising Methods Untuk Efektifitas Periklanan. EXPERT: Jurnal Manajemen Sistem Informasi dan Teknologi, 4(1).

Jananto, J. A. (2014). Sistem Informasi Publik Layanan Kesehatan menggunakan Metode Location Based Service di Kota Semarang. Jurnal Teknologi Informasi DINAMIK Volume 19, No.1, Januari 2014: 59-67 ISSN: 08549524.

Karya Gunawan, B. E. (2015). Implementation of Location Base Service on Tourism Places in West Nusa Tenggara by Using Smartphone. International Journal of Advanced Computer Science and Applications (IJACSA), Vol. 6, No. 8, 2015, 1-7.

Erlangga, E., \& Putra, J. K. (2014, October). Student Satisfaction Analysis of Siater Using End User Computing Statisfaction (EUCS). In International Conference on Engineering and Technology Development (ICETD).

Ragil Tri Dianti Putri, S. K. (2013). Perancangan Aplikasi Location Based Service Rumah Sakit Yogyakarta Pada Android. Seminar Nasional Informatika 2013(semnasIF 2013) ISSN: 1979-2328 UPN "Veteran" Yogyakarta, 18 Mei 2013, 1-7

Santoso, K. I. (2016). Aplikasi Location Based Service Layanan Kesehatan Kota Magelang Berbasis Android. INFOKAM Nomor I Th. XII/MARET/ 2016.

Satriaji Cahyo Nugroho, O. D. (2015). Aplikasi Pencarian Rute Perguruan Tinggi Berbasis Android Menggunakan Location Based Service(LBS) di Kota Semarang. Jurnal Teknologi dan Sistem Komputer (JTsiskom), Vol.3, No.2, April 2015 e-ISSN: 2338-0403, 1-9 
Vithalkar, 1. D. (2014). Providing Emergency Services Using Location Based Tracking on Mobile Devices. International Journal of Science, Engineering and Technology Research (IJSETR), Volume 3, Issue 3, March 2014, 1-7.

Wicak Hidayat \& Sudarma S. (2011). Buku pintar Komputer, Laptop, Notebook \& Tablet. Jakarta Selatan. 


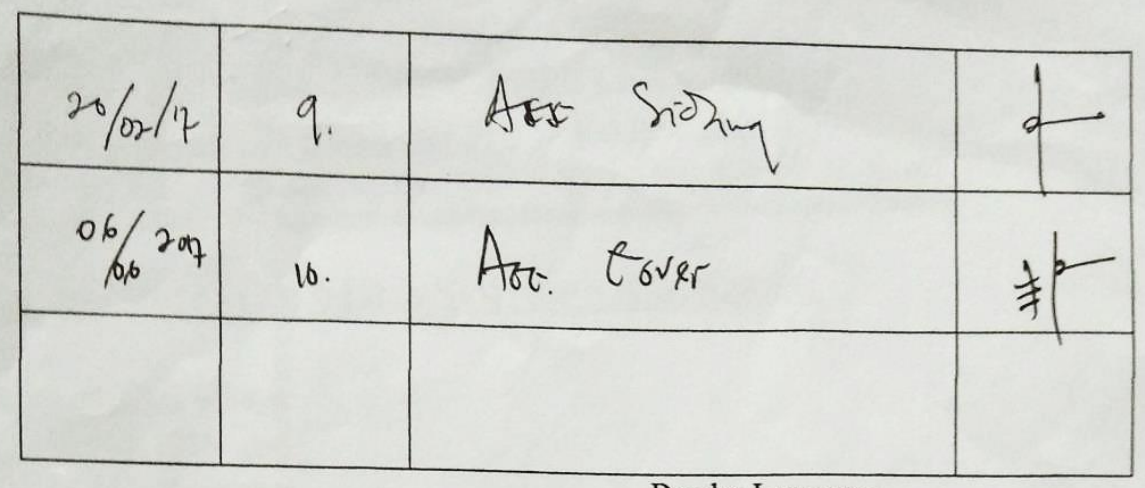

Bandar Lampung,

Dekan

Fakultas Ilmu Komputer

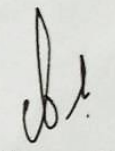

Ahmad Cucus, S.Kom., M.Kom 
Lampiran 2. Form Perbaikan Sidang Penulisan Ilmiah

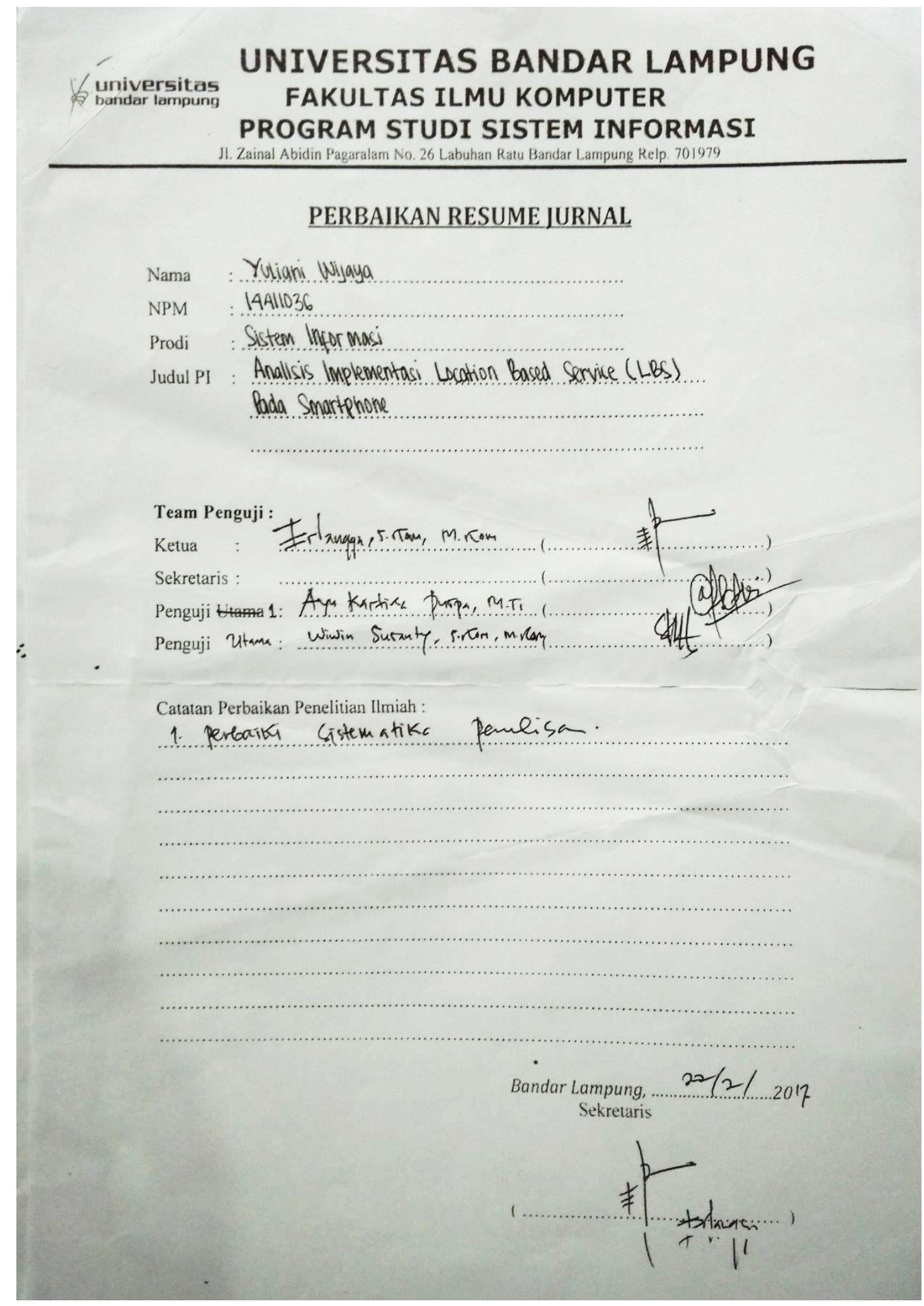




\section{Lampiran 3. Berita Acara Cetak Softcover}

\section{Berita Acara Cetah Soft Cover}

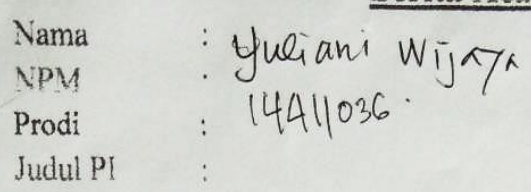

\begin{tabular}{|c|c|c|c|c|}
\hline & \multirow{2}{*}{ Kesesuaian Isi } & \multicolumn{2}{|c|}{ Status } & \multirow{2}{*}{ Ket } \\
\hline & & Sesuai & Tidak & \\
\hline 1. & Cover $\quad 1 \neq 2$ & & V & $\begin{array}{l}\text { Cover } 1 \\
\text { ada perbaikan }\end{array}$ \\
\hline
\end{tabular}

$\begin{array}{ll}\text { 2. Lembar Pengesahan } & \checkmark \\ \text { FOKM I } & \end{array}$

3. Lembar Pengesahan $\checkmark$

4. Sudut Cover (Nama,

5. Motto \& Persembahan Tlak USah

$\therefore$

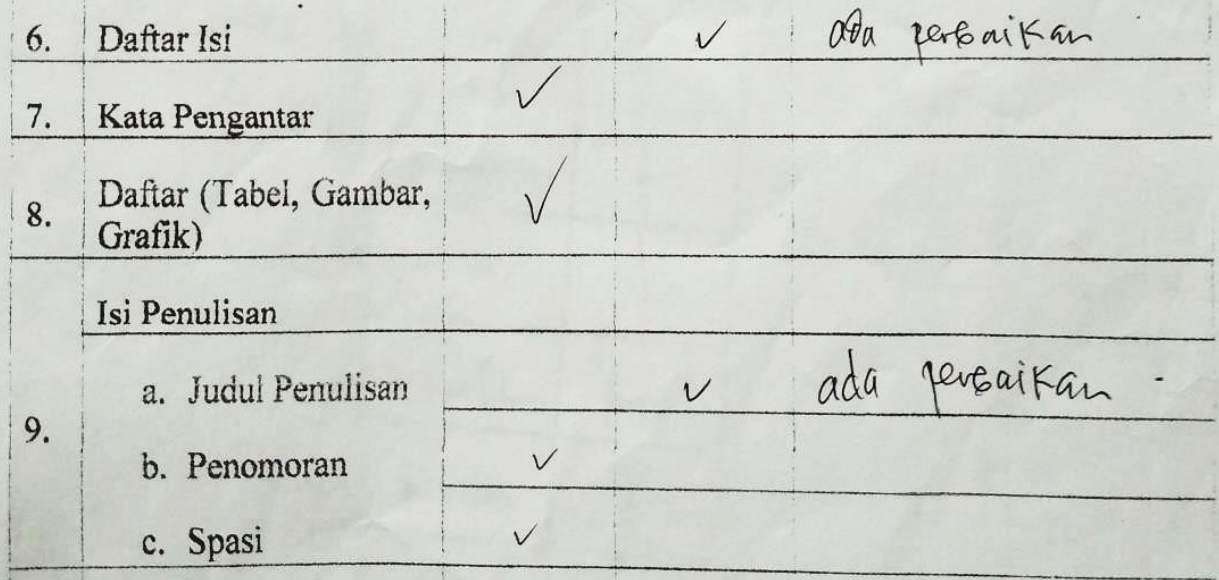

10. Daftar Pustaka

11. Lampiran

$\checkmark$ Pilengkapí

Bandarlampung, 18 Juli 2017 .

IIM

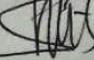

( WIWIn-s 


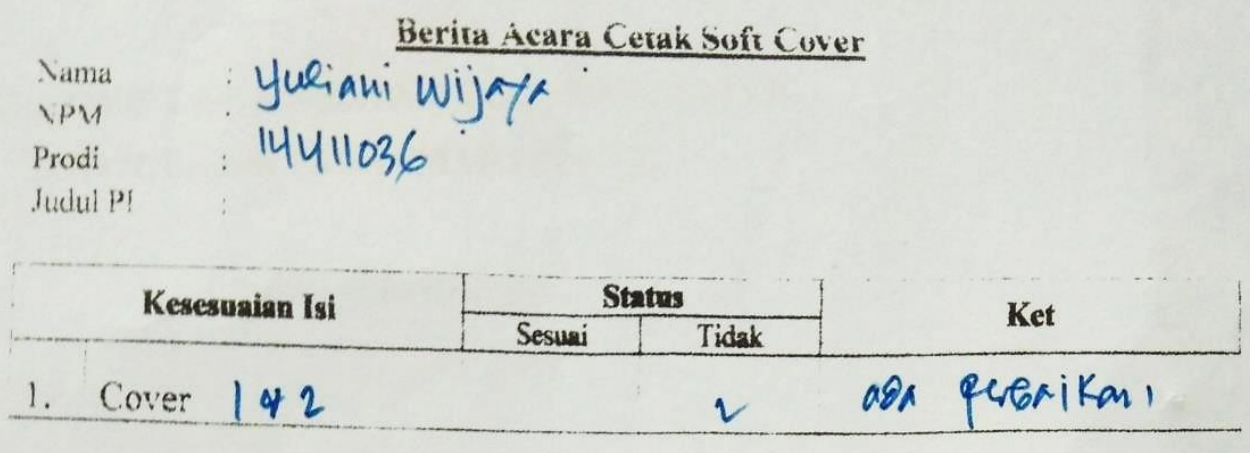

2. Lembar Pengesahan

3. Lembar Pengesahan
FORM 2

4. Sudut Cuver (Nania, 4. NPM, Judul)

5. Motto \& Persembahan

6. Daftar Isi

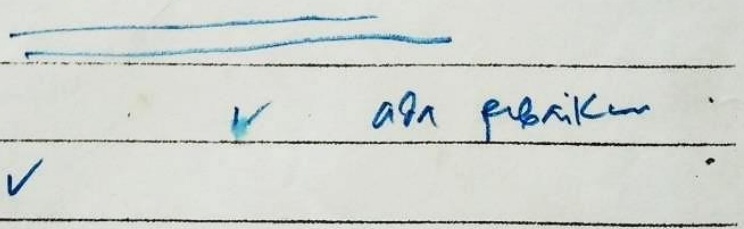

7. Kata Pengantar

8. Daftar (Tabel, Gambar, Grafik)

Isi Penulisan

9.

a. Judul Penulisan

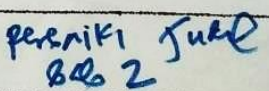

b. Penomoran

c. Spasi

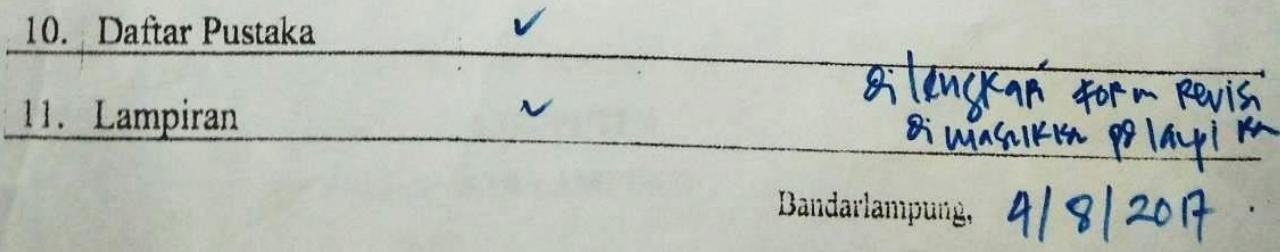
V ACe Cofterver $\frac{5}{2} 2017$ diets

$$
\text { Intets }
$$
( wiwIn: S )

37 